Article

\title{
Impact of COVID-19 and Anti-Pandemic Measures on the Sustainability of Demand in Suburban Bus Transport. The Case of the Slovak Republic
}

\author{
Vladimír Konečný, Mária Brídziková * ${ }^{D}$ and Šimon Senko $\mathbb{D}$ \\ Department of Road and Urban Transport, Faculty of Operation and Economics of Transport and Communications, \\ University of Zilina, 01026 Žilina, Slovakia; vladimir.konecny@fpedas.uniza.sk (V.K.);

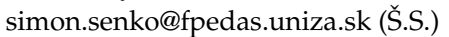 \\ * Correspondence: maria.bridzikova@fpedas.uniza.sk; Tel.: +421-41-513-3523
}

\begin{abstract}
The COVID-19 pandemic has had a major impact on global social and economic development, including the transport sector. To prevent the spread of COVID-19, individual states had to take radical measures, including the closure of schools, offices, and businesses. At present, an extraordinary situation persists in the Slovak Republic in connection to the COVID-19 pandemic, which continues to influence the behavior and decisions of passengers when using public passenger transport. Anti-pandemic measures in the Slovak Republic were reflected in a decrease in the mobility of the population in public passenger transport; the change in mobility manifested to different extents in individual regions of the Slovak Republic. Our research at the regional level is focused on the Žilina self-governing region. The net impact of the COVID-19 pandemic in 2020 was clear through a year-on-year decrease in the number of total passenger transport systems for suburban bus transport (SBT) in ŽSK by $40.2 \%$ in March, in April by $70.0 \%$, and in May by $60.2 \%$. There was a more significant decrease in the number of passengers in the first wave of the pandemic in the first half of 2020 than during the second wave of the pandemic in the second half of 2020. The decrease in demand was most pronounced in April 2020 in pupils and students aged 15 years (-89.3\%), in children under 6 years $(-85.7 \%)$, and in seniors over $65(-80.0 \%)$. A time series of past demand for SBT in the Žilina self-governing region, including data from the pandemic period used for forecasts of single-criteria, reduced the reliability of estimated future values of demand. Estimated future demand values are an important part of SBT's transport service plans for ensuring an adequate supply of transport services in order to maintain demand.
\end{abstract}

Academic Editors: Gonçalo Correia and Marc A. Rosen

Received: 27 February 2021

Accepted: 27 April 2021

Published: 28 April 2021

Publisher's Note: MDPI stays neutral with regard to jurisdictional claims in published maps and institutional affiliations.

Copyright: (c) 2021 by the authors. Licensee MDPI, Basel, Switzerland. This article is an open access article distributed under the terms and conditions of the Creative Commons Attribution (CC BY) license (https:// creativecommons.org/licenses/by/ $4.0 /)$.

Keywords: demand; suburban bus transport; mobility; lockdown; unemployment; passenger behaviour

\section{Introduction}

Transport is one of the indicators for measuring sustainable development through overall energy consumption, transport growth, transport prices, and social and environmental impacts [1]. One of the ways in which residents can make their journeys is to prioritize public passenger transport over individual transport. The challenge for many cities is to at least maintain the current number of passengers using public passenger transport. Polat (2012) [2], Paulley et al., (2006) [3], and Metz (2012) [4] identified in their research several factors by which carriers and customers of transport services can, to some extent, influence the demand for public passenger transport. With the help of the transport policy of individual cities, regions, and states, stabilization of the demand for public passenger transport (PPT) is achievable [5,6]. The relationship between satisfaction with PPT and mode of transport has been investigated by Diana (2012) [7], Cantwell et al., (2009) [8], and Abouhassan (2017) [9].

At the beginning of 2020, the world was hit by an epidemic that was largely unknown to the world. COVID-19 is currently a global pandemic. Currently, among the most 
affected countries are the economies of the G7 countries and China. On their own, the US, China, Japan, Germany, the United Kingdom, France, and Italy account for $60 \%$ of world supply and demand (GDP), $65 \%$ of world production, and $41 \%$ of world exports to production [10]. The response to COVID-19 was that individual countries gradually adopted not only regional restrictions but also nationwide lockdowns [11]. Countries have suspended urban public transport, closed entertainment establishments, and banned public gatherings [12,13]. In selected cities, Abu-Rayash and Dincer (2020) [14] examined the impact on the transport sector and the associated reduction in GHG emissions and energy savings caused by the current pandemic (COVID-19). In the context of the pandemic, they have shown a significant reduction in energy consumption and an associated reduction in GHG emissions. The COVID-19 pandemic has hit the economies of countries across sectors. In particular, the transport sector will take longer to return to its original state compared to other sectors, as evidenced by historical data from previous pandemics. Different countries have different approaches to keeping the economy going and, at the same time, reducing the spread of COVID-19, e.g., Canada and the United Kingdom plan to open their economies and businesses only after the pandemic has been overcome. By contrast, Russia, China, India, and Italy plan to rebuild their economies, despite the current situation. Results show that the majority of the world is in a state of mental distress and will face nervousness and anxiety issues post-COVID-19. Therefore, most of the measures taken in relation to the disease have caused changes in citizens' behavior in order to keep their contact to a minimum and to limit their travel habits. Restrictions in individual countries, whether at the regional or national level, have had a positive effect, on the one hand, as they have reduced the spread of the disease; on the other hand, we can observe negative effects on urban economies, mental health, and transport systems [15,16]. The demand for transport is a derived demand and, with the limitation of activities, there is also a decrease in the demand for public passenger transport. Budd et al., (2020) [17] emphasize in their contribution that the post-pandemic period is a great opportunity to transform PPT. They propose not only to focus on environmentalism (sustainability) but also on the safety and health of passengers and communities. At the same time, they emphasize the importance of individuals as a basis for successful PPT.

The first case of the new COVID-19 disease was reported in the Chinese city of Wuhan, in Hubei Province, from where it spread rapidly around the world. The authors Chen and Pan (2020) [18] describe in their article how the Chinese government and people took strong action to combat COVID-19, and summarize China's experience with transport during this period. Research in the Chinese city of Wuhan, combined with the restrictions adopted, has shown that the closure of Wuhan slowed the spread of the disease to other cities by 2.91 days. Research has also shown that cities that took precautionary measures tended to report fewer cases in the first week of their respective outbreaks, on average, compared to cities that started implementing control measures later [19]. The findings of Li et al. suggest that, during the pandemic, policymakers should prioritize measures to reduce the spread of COVID-19 over the resumption of economic activity [20].

As in other countries of the world, China has seen a rapid decline in public mobility, especially in the area of public passenger transport, which has been largely replaced by individual car transport. For this reason, some service providers have completely stopped their services, such as in Wuhan, China, for example [21], or have allowed the use of public passenger transport only for basic travel, such as some states in the USA and some countries in Asia and Europe [22]. Although public passenger transport services have been provided without restriction in some countries, passengers have limited use of public passenger transport because they fear that they will become infected with the virus [23]. The experience of China was described by Dong et al., (2021) [24] in their contribution, which focused on the perception of safety and passenger satisfaction in public passenger transport during the COVID-19 crisis. This research aims to understand the psychological reactions of passengers to a pandemic. The cross-sectional study was conducted by authors in eight cities in China where public transport systems were temporarily closed due to 
the pandemic. The results indicated that people's feeling of safety is related to overall satisfaction with public transport, but also that people's feeling of anxiety has a negative effect on perceived safety, which also increases if the disease is more severe in a given area. According to the authors, the information associated with the pandemic and transport has a demonstrably greater influence on passengers' decisions. The data obtained can greatly help to better manage future emergencies. Shen et al., (2020) [25] focused their research on preventive and control anti-pandemic measures in China, which seek to present one way to prevent the spread of COVID-19 in PPT in other countries.

According to research conducted in Ghana by Dzisi et al., (2020) [26], which focuses on wearing masks in PPT, scientists are trying to find out how many people are in a vehicle in PPT and how many of them are violating the measures concerning the wearing of protective masks. The research was carried out at a PPT station. These data served as the basis for correlation analysis between the number of infected people and the mobility of the population. Regarding the use of face masks within public transport vehicles, however, there was complete compliance (fewer than 3 people without face masks) about $12.6 \%$ of the time, with mostly partial compliance observed the majority of the time. Complete disregard for the policy on facemasks (fewer than 3 people wearing a mask in a vehicle) also occurred about $21.3 \%$ of the time. On average, 4 people per vehicle were not wearing face masks. These results suggest the existence of a significant gap in the implementation of the policy on face masks and the need for much more effective implementation of the policy.

Arellana et al., (2020) [27] examines the short-term effects on transport systems caused by various measures taken by the government in Colombia. Using official and secondary data on Colombia's seven largest cities, the authors analyzed the impact on three components of the transport sector-freight transport, air transport, and urban public transport. The results of the paper show that the measures have greatly reduced the demand for travel and congestion in the transport system, reduced the number of passengers, and, also, reduced the negative impact on the environment. During the first three months of measures in the country, freight transport was reduced by $38 \%$, which affected the supply chain of products that are not essential to citizens' lives. According to many other experts, public passenger transport is one of the sectors most affected by the COVID-19 pandemic.

Hansher et al., (2021) [28] pointed out in their contribution a short-term reduction of financial and time costs associated with the reduction of mobility in both individual and public passenger transport in the Sydney area. The authors investigated how mobility changed during the restrictions, even at the beginning of the release of measures. The problem of financing was encountered by several carriers, so it is appropriate that the state or another public administration body should help with co-financing.

However, the pandemic also greatly affected aviation and the aviation industry in general. In aviation, several restrictions have been introduced, leading to serious long-term impacts on the global aviation industry. Nižetić (2020) [29] analyzed air mobility in Europe on the basis of available data from relevant sources related to the aviation industry.

Jenelius and Cebecauer (2020) [30], in regions of Sweden (Skåne, Västra Götaland, and Stockholm), examined how COVID-19 affected passenger mobility, using data from carrier handling systems. Of these regions, Stockholm was most affected by COVID-19 cases between March and May 2020. At the same time, the decrease in passengers was the largest in this region (about 60\%), while, in Västra Götaland, the decrease was the smallest (about $40 \%$ ). As the situation improved, passenger mobility also gradually increased, but was still lower than in the previous year. Ultimately, public passenger transport was the most affected mode of transport. The decrease in the number of passengers stems mainly from the reduction in the number of active passengers by public transport, while the average daily number of journeys per active passenger has remained relatively stable. The change was also observable in types of ticket purchased. The data point to increased demand for one-off and electronic travel tickets, while monthly travel tickets saw a decline in sales. The sale of short-term tickets has fallen sharply, as these types of tickets are mainly used by tourists. The results of the research are not clear as to whether the use of different types of 
public passenger transport (PPT) is influenced by demography. However, these differences have been shown to have an impact on PPT funding. In short, passengers have changed their mobility and decision-making significantly by leaving the PPT system. Of those who remained, many switched to more flexible ticket types. Part of the slight recovery in passenger numbers, in the second half of the period, was due to the return of public transport passengers.

In their contribution, Wielechowski et al., (2020) [31] set the objective of evaluating changes in public transport mobility in Poland as a result of the COVID-19 pandemic. The authors analyzed the traffic situation at the national and regional level in the period from 2 March to 19 July 2020, during the first wave of the pandemic. According to research into the relationship between human mobility in PPT and the number of new cases in Poland, there is an indirect, insignificant relationship. The strength and statistical significance of the correlation vary considerably from one voivodeship to another. The opposite case can be seen between the change in mobility in PPT and the measures taken by the Polish government, where there was a statistically significant but strong indirect relationship between the examined variables at national and regional levels. The strength and statistical significance of the correlation varies considerably from one voivodeship to another. The results suggest that the anti-pandemic measures taken by the Polish government have reduced mobility in PPT more than would be limited by the development of the epidemic itself. Research by Tarkowskii et al., (2020) [32] sought to explain social responses to mobility restrictions. The difference in mobility regarding visits to parks, shops and pharmacies varies considerably between voivodeships. One way to explain these differences is through long-term habits of social life. Historical and cultural factors are most likely behind the similarity. Reductions in mobility and changes in mobility patterns are obvious effects of social distance. As regards the regional dimension, mobility has been steadily declining in most of the areas analyzed. In the local context, illustrated by an analysis of travel time changes from residential areas in Gdańsk, Gdynia and Sopot to the Gdańsk-Oliwa business and science center, there has been a noticeable but spatially diversified reduction in driving time (by private car). The most significant reduction in travel time has been recorded in the peripheral areas accessible by high-speed roads, which are usually congested during peak periods. Restrictions on mobility have led to a high reduction in congestion, which, in turn, has led to shorter travel times. Borkowski et al., (2021) [33] have focused their research on the effects of the pandemic on the transport system in relation to daily commuting, especially over short distances. The authors examined the factors influencing the change in travel times and the change in the share of transport systems within the pandemic. A CATI survey with a representative sample of 1069 inhabitants within Poland between March and April 2020 was used. A GLM (General Linear Model) was used to analyze the data, which allowed the authors to include all qualitative and quantitative variables. The research found significant reductions in travel times, regardless of age and gender, related to the purpose of the trips, means of transport, system size, fear of the virus, employment, and changes caused by the pandemic. Research results from Ciechanski (2020) [34] point to the fact that suburban passenger transport, which relies most on student travel for funding, has been decimated after March and April 2020. Particularly affected are private carriers from sparsely populated regions, which, in some cases, are partially but largely deprived of revenue. The author is concerned that some parts of Poland, which are served by private carriers, may not open schools after the end of the pandemic, as there will be no one to transport pupils. As a result, he recommends that the state acts swiftly to ensure that these regions are served. De Vos (2020) [15], but also Arellana et al., (2020) [27], also pointed out that a declining number of passengers during a pandemic has an impact on the financing of public passenger transport.

Research by Coppola and Fabiis (2021) [35] focused on the impact of anti-pandemic measures (social distancing) in passenger rail transport in Italy. A specific case is two case studies, which differ in the principles of demand (urban and suburban) and the transport system (free capacity vs. the need to reserve a seat on the train). The results point to the 
unsustainability of these measures in the medium term, as it has been shown that, in urban trains (similar to the metro system) with free capacity, they are overcrowded at peak hours. The authors' recommendation is to increase the capacity of trains by $70-80 \%$, which would be possible by compressing the connections or by using a higher number of wagons. At the same time, however, they add that this would have a negative impact on the financing of these trains, as a case study of suburban trains estimated a decrease in ticket sales by $20-60 \%$.

In his contribution, Bucsky (2020) [36] shares a case study in which he argues that the reduction in mobility is not the same for all modes of transport, with the largest decrease being in the case of public passenger transport. The author states that understanding the development of the share of individual transport systems during a pandemic situation can help cities to better prepare for traffic management in the future, even in the event of emergencies and events. The analysis showed that urban public transport in Budapest saw a reduction in demand of $80 \%$, while bicycle transport dropped by $23 \%$ and shared bicycles by $2 \%$. Logically, the largest increase in intensity was recorded by individual car transport. The fact that most people started working at a "home office" during the pandemic [37,38] also contributed significantly to this decrease in passengers, which is currently the case in the whole of the Slovak Republic.

As abroad, the effects of the COVID-19 pandemic were significant in the conditions of the Slovak Republic and the Žilina Region. A pandemic influences the behavior and decisions of passengers to use public passenger transport. The pandemic situation has caused changes in passenger behavior. Among the recommendations of the Pandemic Commission and the Public Health Office of the Slovak Republic, if necessary, is the use of a car instead of public passenger transport in order to reduce the risk of infection.

The aim of our paper is to examine the impact of the pandemic caused by COVID19 on the change in population mobility in relation to public passenger transport. This goal is achieved through subgoals. The first partial goal is the research of changes in the overall mobility of the population, based on global data on changes in mobility in 2020 by regions of the Slovak Republic. Here, the intention is to identify interregional differences in the change in population mobility in relation to anti-pandemic measures taken at the national level. Each transport system is unique and specific, and the impact of the COVID-19 pandemic needs to be examined on a specific transport system and its evolving demand. Part of the research is therefore focused on a specific transport system of suburban bus transport in the Žilina self-governing region. The research is related to the second sub-objective, which is to identify the net impact of the pandemic on the change in demand of groups of passengers and passengers as a whole in the SBT, based on an assessment of the pre-outbreak of the COVID-19 epidemic and the subsequent 2020 pandemic. The impact of the pandemic must also be seen in the broader contexts of ensuring transport services in the area, drawing up transport service plans, including future transport demands for passengers, sustaining demand, and ensuring an adequate supply of transport services. Therefore, another partial goal of the paper is to assess the impact of the pandemic on estimating the future level of demand using a single-criteria time series of passenger demand. The intention is to identify the impact of the COVID-19 pandemic on the accuracy and reliability of short-term forecasting of a single-criteria time series of passenger demand.

\section{Materials and Methods}

\subsection{Data}

Several groups of data were used to carry out our research in the area of the impact of COVID-19 and anti-pandemic measures on the sustainability of demand and supply in suburban bus transport in the conditions of the Slovak Republic and the Žilina selfgoverning region. 


\subsubsection{Data on Changes in Population Mobility in the Regions of the Slovak Republic}

We obtained data on the change in passenger mobility from an overview of public movement at public passenger transport stations during the pandemic. These data were collected by Google. Their aim was to provide an overview of changes in mobility in response to the COVID-19 pandemic and measures to combat the pandemic. The reports show trends in movement by time and region, in locations of different categories. In our research, these were public transport stations, and we used a regional perspective (all 8 self-governing regions), as well as the Slovak Republic as a whole. The aim of using the data was to examine how mobility in individual localities in individual self-governing regions, and in the whole of the Slovak Republic, had changed in connection with the measures taken in individual periods.

\subsubsection{Data on Demand and Supply in Suburban Bus Transport in the Žilina Self-Governing Region}

To investigate the impact of the COVID-19 pandemic on demand and supply in suburban bus transport, consolidated data were provided for the Žilina Region from customers of the Žilina self-governing region and from carriers providing transport services by suburban bus transport in this region. These are data on the number of passengers carried by groups of passengers, suburban bus fares, and the handling system that includes 10 groups of passengers.

These are a time series of data on the number of transported passengers in individual months, according to individual groups, on the basis of the SBT tariff in the Žilina selfgoverning region. The time series of data are for the period from January 2013 to October 2020. These are unique data obtained from the Žilina self-governing region as the client of services in the public interest in suburban bus transport. These are data from the handling systems in the vehicles of SBT carriers; on the basis of the types and numbers of tickets sold, carriers are obliged to provide this data to the Žilina self-governing region. Data on the demand of individual groups of passengers by months for the Žilina Region for individual years before the outbreak of the COVID-19 pandemic from 2013 to October 2020 were also provided. The data were necessary for research into the change in demand due to the 2020 pandemic and in relation to the development of demand before the pandemic itself. Data are also available on supply, for the number of kilometers covered by carriers in suburban bus transport in the region under study, for the years preceding the outbreak of the COVID-19 pandemic from 2013 to October 2020.

The Slovak Republic is divided into 8 self-governing regions, and 1of these 8 regions is the Žilina self-governing region, which is located in the north-western part of Slovakia (Figure 1). The region borders the Czech Republic in the west of its territory and Poland in the north. According to available data, ŽSK has 690,434 inhabitants, and the total area of the region is $6809 \mathrm{~km}^{2}$ [39].

\subsubsection{Information on Anti-Pandemic Measures Taken in the Slovak Republic}

Important anti-pandemic measures taken in the Slovak Republic in connection with reducing the spread of COVID-19 were drawn from available databases on the websites of the Ministry of Health of the Slovak Republic [40], the Public Health Office of the Slovak Republic [41], and korona.gov.sk [42]. Using data provided by Google [43], we examined how the mobility of the population and its changes at public passenger transport stations in the Slovak Republic, as a whole and in individual self-governing regions, developed during the COVID-19 pandemic.

\subsection{Methods}

The following methods were used to investigate the impact of the COVID-19 pandemic on PPT demand. 


\subsubsection{Average Year-on-Year Change in Demand before the COVID-19 Pandemic Brake out}

The level of demand and supply evolves over time. Our aim was to identify the change in demand and supply in suburban bus transport caused by COVID-19. In addition to the impact of COVID-19, the change in demand and supply in 2020 was also influenced by other factors that determined the development of demand and supply, even before 2020 .

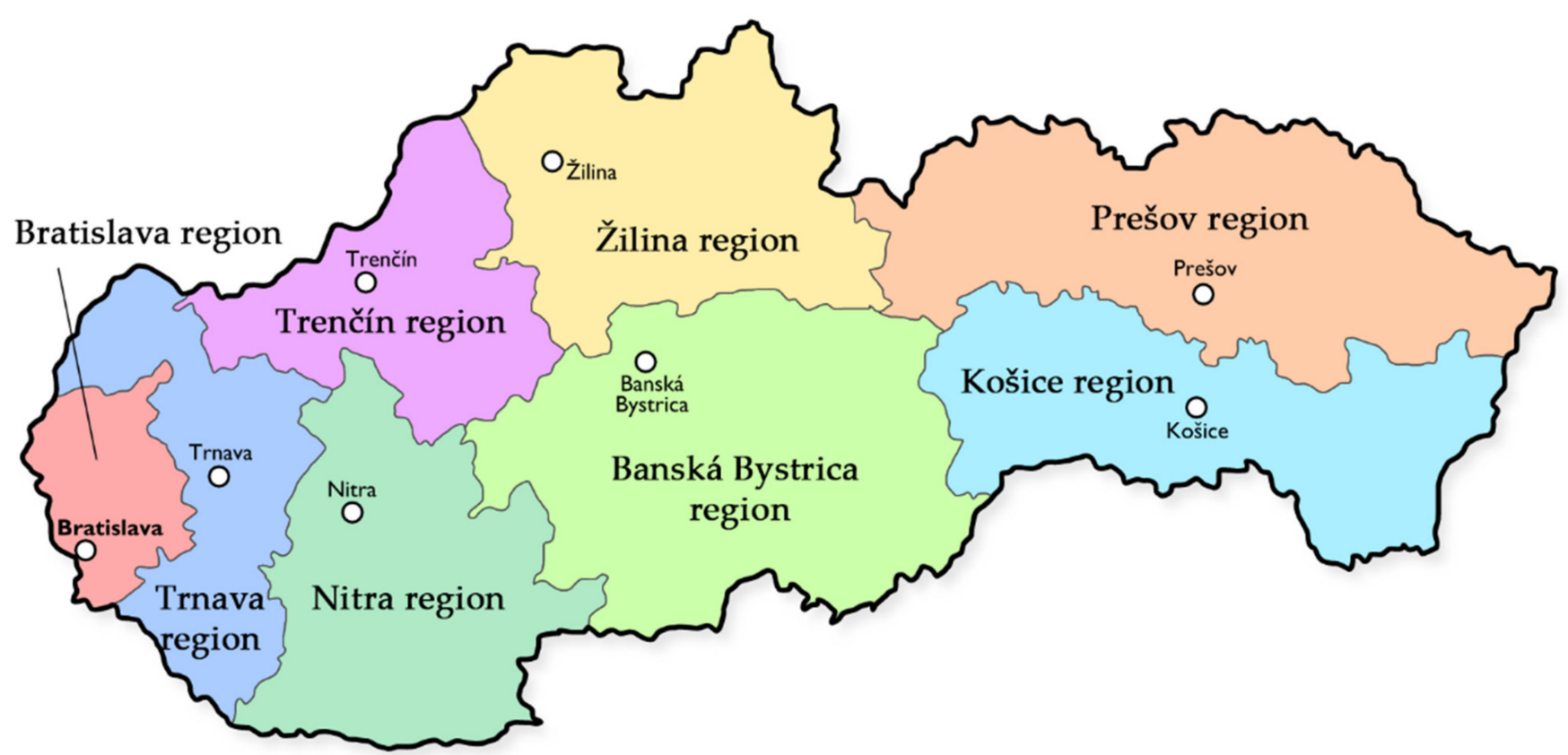

Figure 1. Division of the Slovak Republic into self-governing regions. Sources: Elaborated by the authors.

In our research, we applied the following procedure and relationships for assessing changes in the values of the time series of passenger demand, in the period from 2013 to 2020 .

An average year-on-year change indicator was used to assess the development of supply and demand and their changes before the outbreak of the COVID-19 pandemic.

The change in time series values between the following two periods can be calculated using the time series value change index:

$$
I_{t}=\frac{D_{t}}{D_{t-1}}
$$

where

$t$-the time period, $t=2,3, \ldots, n$;

$I_{t}$ - the index of change in time series values;

$D_{t}$ 一the value of the time series member for the period $t$;

$D_{t-1}$ - the value of the time series member for the period $t-1$.

Using individual indices of year-on-year changes in time series values, it is possible to calculate the average index of change in time series values, Equation (2):

$$
\overline{I_{t}}=\sqrt[n-1]{I_{2} \times I_{3} \times \ldots \times I_{n}}=\sqrt[n-1]{\frac{D_{2}}{D_{1}} \times \frac{D_{3}}{D_{2}} \times \ldots \times \frac{D_{n}}{D_{n-1}}}=\sqrt[n-1]{\frac{D_{n}}{D_{1}}}
$$

where

$\overline{I_{t}}$ - the average index of change in time series values;

$n$-the number of time series members;

$D_{1}$ - the value of the 1 st member of the time series; 
$D_{n}$ - the value of the $n$th member of time series.

We use Equation (2) and calculate the average percentage change of the time series values using the Equation:

$$
\overline{K_{t}}=\left(\overline{I_{t}} \times 100\right)-100=\left(\sqrt[n-1]{\frac{D_{n}}{D_{1}}} \times 100\right)-100=\left(\sqrt[n-1]{\frac{D_{n}}{D_{1}}}-1\right) \times 100[\%]
$$

where $\overline{K_{t}}$-is the average percentage change in time series values.

If the data on demand (number of passengers) in individual years are by months and the demand is broken down by individual groups of passengers, then the average year-on-year percentage change in demand of a particular group of passengers " $g$ " for the month of year " $m$ " is calculated using the adjusted Equation (3):

$$
\overline{K_{t}}=\left(\sqrt[n-1]{\frac{D_{g, m, n}}{D_{g, m, 1}}} \times 100\right)-100=\left(\sqrt[n-1]{\frac{D_{g, m, n}}{D_{g, m, 1}}}-1\right) \times 100[\%]
$$

where

$D_{g, m, n}$ - the demand of the group of passengers " $g$ " in month " $m$ " in the last year of the time series;

$D_{g, m, 1}$ - the demand of the group of passengers " $g$ " in month " $m$ " in the first year of time series.

We are considering a time series of data from 2013 to 2019. We did not consider older data from before 2013 in the research due to the impact of the financial and economic crisis on the demand for suburban bus transport in the Slovak Republic.

\subsubsection{Year-on-Year Change in Demand in 2020 Compared to 2019}

This is a calculation of the change in demand in the pandemic year of 2020 compared to the value of demand in the year before 2020. The impact of COVID-19 on passenger demand in the pandemic year of 2020 can be expressed by the demand change index in 2020 compared to 2019:

$$
I \text { COVID }=\frac{D_{2020}}{D_{2019}}
$$

where

I COVID—-the impact of the pandemic on passenger demand;

$D_{2020}$ - passenger demand in 2020;

$D_{2019}$ - passenger demand in 2019.

By converting to a percentage, we obtain a relationship for the percentage change in passenger demand in the pandemic year of 2020:

$$
\text { I COVID }=\frac{D_{2020}}{D_{2019}} \times 100[\%]
$$

The change in demand of the group of passengers " $g$ " in a specific month " $m$ " of the pandemic year of 2020 in percentage terms is calculated according to the Equation:

$$
I \text { COVID }=\frac{D_{g, m, 2020}}{D_{g, m, 2019}} \times 100[\%]
$$

\subsubsection{Net Impact of COVID-19 on Demand Change}

Demand in the pandemic year of 2020 was also influenced by other demand factors that influenced its development before the outbreak of the pandemic itself (price, population income, population structure, quality of transport service, etc.). We assume that these factors also affected demand in the pandemic year of 2020. Therefore, it is necessary 
to adjust the change in demand in the pandemic year of 2020 by the influence of factors that influenced it even before the pandemic (we consider the period from 2013 to 2019). Therefore, we determine the net impact of COVID-19 on the percentage change in demand for suburban bus transport. We evaluate the development before the pandemic using Equation (3). We calculate the net effect of a pandemic on the change in passenger demand using Equations (3) and (6), we obtain Equation (8):

$$
\begin{aligned}
\text { NI COVID }= & \text { I COVID }-\overline{K_{t}}=\frac{D_{2020}}{D_{2019}} \times 100-\left(\sqrt[6]{\frac{D_{2019}}{D_{0013}}}-1\right) \times 100 \\
& =\left(\frac{D_{2020}}{D_{2019}}-\left(\sqrt[6]{\frac{D_{2019} D_{2013}}{D_{2013}}}\right)\right) \times 100[\%]
\end{aligned}
$$

where

NI COVID—-the net impact of the pandemic on passenger demand;

$D_{2013}$ - passenger demand in 2013.

The net effect of a pandemic on the change in demand of the group of passengers " $g$ " in a specific month " $m$ " of the pandemic year of 2020 in percentage terms is calculated according to the Equation (9):

$$
\begin{gathered}
\text { NI COVID } D_{g, m}=\frac{D_{g, m, 2020}}{D_{g, m, 2019}} \times 100-\left(\sqrt[6]{\frac{D_{g, m, 2019}}{D_{g, m, 2013}}}-1\right) \times 100 \\
=\left(\frac{D_{g, m, 2020}}{D_{g, m, 2019}}-\left(\sqrt[6]{\frac{D_{g, m}, 2019}{D_{g, m .2013}}}-1\right)\right) \times 100[\%]
\end{gathered}
$$

where NI COVID $D_{g, m}$ — the net effect of the pandemic on passenger demand " $g$ " in month " $m$ ".

\subsubsection{Net Impact of the Pandemic on Total Passenger Demand}

The net effect of a pandemic on the change in total passenger demand (for all groups of passengers) in a given month of the pandemic year of 2020, in percentage terms, is calculated according to the Equation (10). Demand values have been available since 2013, ie 2013 is the first year of the time series of passenger demand values:

$$
\begin{gathered}
\text { NI COVID }=\frac{\sum_{g=1}^{r} D_{g, m, 2020}}{\sum_{g=1}^{r} D_{g, m, 2019}} \times 100-\left(\sqrt[6]{\frac{\sum_{g=1}^{r} D_{g, m, 2019}}{\sum_{g=1}^{r} D_{g, m, 2013}}}-1\right) \times 100 \\
=\left(\frac{\sum_{g=1}^{r} D_{g, m, 2020}}{\sum_{g=1}^{r} D_{g, m, 2019}}-\left(\sqrt[6]{\frac{\sum_{g=1}^{r} D_{g, m, 2}, 2019}{\sum_{g=1}^{r} D_{g, m, 2013}}}-1\right)\right) \times 100[\%]
\end{gathered}
$$

where

$g$-a group of passengers within the meaning of a suburban bus fare, $i=1, \ldots r$, in suburban bus transport in Žilina self-governing region $r=10$;

$m$-the relevant month of the year;

$r$-the number of groups of passengers in the suburban bus transport in the Žilina selfgoverning region, $r=10$;

$\sum_{g=1}^{r} D_{g, m, 2020}$ - the total demand for all groups of passengers in month " $m$ " of the year 2020;

$\sum_{g=1}^{r} D_{g, m, 2019}$ - the total demand for all groups of passengers in month " $m$ " of the year 2019;

$\sum_{g=1}^{r} D_{g, m, 2013}$-the total demand for all groups of passengers in month " $m$ " of the year 2013.

2.2.5. Impact of the COVID-19 Pandemic on Short-Term Forecast of One-Dimensional Time Series of Passenger Demand

In the conditions of the Slovak Republic, Act no. 56/2021, The Collection of Laws on Road Transport imposes an obligation on customers of transport services in the public interest (cities and self-governing regions) to draw up a transport service plan (Section 20 of the Act) to ensure the transport service of a territory. Part of transport service plans is also the obligation to estimate short-term future demand for public passenger transport (number of transported passengers) in order to finance these services in the public interest by cities and municipalities, as well as ensuring adequate public passenger transport to ensure transport services in a given area. It is also the basis for concluding a contract 
for transport services between carriers and customers of transport services in the public interest of passenger transport.

The compiled and analyzed single-criteria time series of the number of transported passengers by SBT in the Žilina self-governing region, which we used for assessing the impact of the pandemic on the change in passenger demand in Section 3.2, was also used for short-term forecasting of the number of transported passengers. The aim was to assess the impact of the COVID-19 pandemic on short-term passenger demand forecasts and their reliability.

SAS software was used for short-term demand forecasting, and the basic forecast tool was applied with two possible forecast methods: stepwise autoregressive and exponential smoothing.

The Stepwise autoregressive method was used by default. This method fitted a time trend model to the series and took the difference between each value and the estimated trend. Then, the remaining variation was fitted by using an autoregressive model [44].

Exponential smoothing fitted a trend model so that the most recent data were weighted more heavily than data in the early part of the series. The weight of an observation was a geometric (exponential) function of the number of periods that the observation extended into the past, relative to the current period [44].

The suitability of the methods will be verified by drawing up a short-term ex-post forecast for the number of passengers carried for 2019. A forecast will be made for a period with already known data on the actual number of passengers in each month of 2019. The forecast and actual data will be compared.

\subsection{Research Question}

Research question no. 1: Is there a connection between the change in passenger demand for SBT in the Žilina Region and the change in mobility at public transport stations in the Žilina self-governing region in the pandemic year of 2020 ?

The research question synthesizes 2 approaches to the impact of the COVID-19 pandemic on passenger demand and changing mobility.

We will examine the impact of the COVID-19 pandemic on the change in population mobility from 2 information sources characterized in Section 2.1, focusing on changing passenger demand for SBT in the Žilina Region and the impact of the COVID-19 pandemic on changing mobility at public transport stations in the Žilina Region from data [43] in the pandemic year of 2020 .

Research question no. 2: What effect does the COVID-19 pandemic have on the forecasts of a one-dimensional time series of passenger demand?

\section{Results}

\subsection{Impact of Adopted Anti-Pandemic Measures on Reducing the Mobility of the Population}

The COVID-19 disease caused a reduction in the mobility of the population not only in Slovakia but also the world. The reduction of mobility is based on the measures taken by individual cities, regions, and states. In order to prevent the spread of the disease, individual countries started to close shops, shopping centers, schools, and offices. On the one hand, these measures reduced the rate of the disease, but, on the other hand, they had an impact on the demand for bus transport, as residents decided to use cars or public passenger transport services to make their journeys.

One of the aims of the research is to evaluate how the measures taken by the government of the Slovak Republic affected the mobility of the country's population. We examined the change in the mobility of the population in relation to the use of public passenger transport services.

Table 1 shows percentage changes in the mobility of the population for individual selfgoverning regions and the Slovak Republic as a whole, which occurred at public transport stations in connection with the measures taken by the government. These percentage 
changes are based on baseline mobility. The basis is the mobility of the population in the period from 6 January 2020 to 3 February 2020.

Table 1. Percentage change of population mobility in individual self-governing regions of the Slovak Republic and the whole Slovak Republic. Source: Developed by the authors on the basis of [43].

\begin{tabular}{|c|c|c|c|c|c|c|c|c|c|c|}
\hline \multirow[b]{2}{*}{ Date } & \multirow{2}{*}{ Event } & \multicolumn{8}{|c|}{$\%$ Change in Mobility in Self-Governing Regions } & \multirow[b]{2}{*}{ SK } \\
\hline & & BA & ZA & BB & KE & NR & PO & TN & TT & \\
\hline 29 February 2020 & State of mobility at the end of the month & 14 & 3 & 14 & 11 & 15 & -9 & 18 & 8 & 11 \\
\hline 6 March 2020 & The first confirmed case of COVID-19 in the SR & -3 & -3 & -2 & -17 & -2 & -14 & 2 & 1 & -5 \\
\hline 15 March 2020 & Declaration of a state of emergency & -61 & -60 & -51 & -55 & -50 & -64 & -52 & -51 & -56 \\
\hline 31 March 2020 & State of mobility at the end of the month & -66 & -62 & -52 & -58 & -52 & -55 & -52 & -57 & -60 \\
\hline 21 April 2020 & Multi-phase program for loosening restrictions & -58 & -51 & -45 & -50 & -42 & -46 & -39 & -50 & -52 \\
\hline 22 April 2020 & First phase of loosening of restrictions & -58 & -52 & -44 & -49 & -43 & -47 & -42 & -50 & -52 \\
\hline 30 April 2020 & State of mobility at the end of the month & -53 & -45 & -37 & -45 & -36 & -39 & -31 & -47 & -46 \\
\hline 6 May 2020 & Second and third phase of loosening of restrictions & -53 & -49 & -35 & -45 & -36 & -46 & -36 & -44 & -47 \\
\hline 20 May 2020 & Fourth phase of loosening restrictions & -37 & -31 & -25 & -33 & -20 & -30 & -20 & -32 & -32 \\
\hline 31 May 2020 & State of mobility at the end of the month & -66 & -50 & -43 & -54 & -44 & -57 & -34 & -42 & -56 \\
\hline 3 June 2020 & Fifth phase of loosening restrictions & -27 & -25 & -22 & -25 & -12 & -26 & -14 & -22 & -24 \\
\hline 14 June 2020 & End of the state of emergency in the Slovak Republic & -43 & -12 & -26 & -22 & -17 & -18 & 13 & -5 & -28 \\
\hline 22 June 2020 & Opening of schools on voluntary basis & -21 & -15 & -9 & -11 & -9 & -12 & 0 & -17 & -15 \\
\hline 30 June 2020 & State of mobility at the end of the month & -12 & -1 & 10 & 5 & 6 & 26 & 20 & -1 & -1 \\
\hline 31 July 2020 & State of mobility at the end of the month & -29 & -13 & -8 & -17 & -16 & 28 & 11 & -13 & -17 \\
\hline 11 August 2020 & Second wave of pandemic in SR & -22 & -7 & -1 & -13 & -14 & 41 & 8 & -17 & -12 \\
\hline 31 August 2020 & State of mobility at the end of the month & -29 & -8 & - & -8 & - & - & - & - & -14 \\
\hline 30 September 2020 & State of mobility at the end of the month & -18 & -1 & -4 & -12 & 4 & -3 & 8 & 0 & -11 \\
\hline 1 October 2020 & Declaration of a state of emergency in the SR & -23 & -6 & -2 & -14 & 2 & -8 & 2 & -7 & -14 \\
\hline 12 October 2020 & Interruption of classroom learning in high schools & -39 & -29 & -26 & -26 & -25 & -19 & -20 & -26 & -30 \\
\hline 24 October 2020 & Lockdown & -64 & -56 & -44 & -57 & -43 & -59 & -47 & -41 & -56 \\
\hline 26 October 2020 & Closing of all schools & -53 & -47 & -41 & -48 & -41 & -41 & -35 & -34 & -46 \\
\hline 28 October 2020 & Lockdown extension to 8.11 .2020 & -52 & -46 & -39 & -47 & -37 & -40 & -35 & -36 & -47 \\
\hline 31 October 2020 & First round and first day of mass testing & -44 & -47 & -41 & -33 & -24 & -58 & -47 & -40 & -40 \\
\hline 1 November 2020 & First round and second day of mass testing & -63 & -60 & -51 & -47 & -45 & -53 & -52 & -45 & -55 \\
\hline 7 November 2020 & Second round and first day of mass testing & -42 & -35 & -20 & -32 & -18 & -39 & -25 & -27 & -34 \\
\hline 8 November 2020 & Second round and second day of mass testing & -44 & -35 & -34 & -31 & -25 & -32 & -23 & -30 & -36 \\
\hline 9 November 2020 & Change in the exceptions from lockdown & -47 & -38 & -28 & -36 & -32 & -25 & -25 & -35 & -38 \\
\hline 16 November 2020 & Loosening of restrictions & -42 & -31 & -26 & -28 & -30 & -19 & -23 & -32 & -33 \\
\hline 30 November 2020 & state of mobility at the end of the month & -37 & -23 & -24 & -23 & -24 & -20 & -14 & -26 & -28 \\
\hline 19 December 2020 & Lockdown & -57 & -37 & -35 & -43 & -34 & -44 & -32 & -6 & -45 \\
\hline 29 December 2020 & Extension of the state of emergency & -64 & -49 & -46 & -52 & -48 & -19 & -45 & -53 & -54 \\
\hline 31 December 2020 & Tightening of anti-pandemic restrictions_lockdown & -71 & -61 & -54 & -64 & -59 & -39 & -57 & -68 & -65 \\
\hline
\end{tabular}

Legend: BA-Bratislava region, BB-Banská Bystrica region, KE-Košice region, NR-Nitra region, PO—Prešov region, TN-Trenčín region, TT-Trnava region, $\mathrm{ZA}$-Žilina region, SK-Slovak republic.

The first case of COVID-19 in Slovakia was confirmed on 6 March 2020. Gradually, more cases were added and, by mid-March 2020, it was already in the tens per day. Many experts feared that the low number of patients with the confirmed disease was the result of insufficient testing, and experts also pointed to Slovakia's unpreparedness for the coming pandemic. Extensive preventive measures have been taken since 13 March 2020 to prevent the explosive spread of the disease and, on 15 March 2020, the government of the Slovak Republic declared a state of emergency, which closed retail establishments, schools, offices, and some businesses. During the emergency, some companies suspended production, some adjusted their shifts, and some operated without restrictions, but with the application of safety rules. By declaring a state of emergency on 15 March 2020, there was a 50 to 60 percent decrease in mobility within public transport for all self-governing regions. For 
the whole of the Slovak Republic, on 15 March 2020, a decrease of 56\% in the mobility of the population at public transport stations was recorded, compared to the initial value. These relatively strict measures have resulted in a reduction in passenger mobility and, at the same time, significantly reduced the spread of the disease, thanks to which, at the end of May 2020, about 1500 infected and 28 victims were identified in Slovakia; during June, these numbers increased minimally. With the favorable development of the pandemic, anti-pandemic measures were gradually relaxed, similar to other countries with favorable developments of the situation. This favorable development in the field of COVID-19 was also reflected in an increase in mobility. Within the Trenčín self-governing region, on 14 June 2020 (the government declared the end of the state of emergency), there was an increase in mobility of $13 \%$ compared to the initial state. A similar situation occurred in August within the Prešov Region, where an increase of $41 \%$ was recorded, as well as in the Trenčín Region by $8 \%$, compared to the initial value.

The worsening of the epidemiological situation in September 2020 led to a tightening of measures but, clearly, they have been insufficient; since October 2020 Slovakia has been one of the most affected countries in Europe [41]. Based on the deteriorating situation, the government of the Slovak Republic declared a second state of emergency on 1 October 2020, which was to last 45 days (until 14 November 2020). There was a significant decrease in the mobility of the population in connection with public transport after the interruption of full-time teaching at high schools. From this moment until the end of the year, the mobility of the population again reached similar values to March 2020. The fact that nationwide testing took place in our territory did not increase the use of public passenger transport (the first round of nationwide testing took place from 31 October to 1 November 2020, where the aim was to limit mobility to positive citizens). Subsequently, in the period from 7 to 8 November 2020, the second round of area-wide testing took place in the "red" districts, where the share of positive cases was more than $0.69 \%$. After nationwide testing, exceptions to the curfew were changed from 9 November 2020, and, from 16 November 2020, facilities for art performances, fitness centers, swimming pools, and churches were gradually opened, subject to strict hygiene rules. With the loosening of the measures, the situation began to deteriorate again when, on 26 November 2020, the total number of persons tested by PCR tests exceeded the limit of 100,000 inhabitants. However, due to the worsening situation, the state of emergency was extended twice more-first until 29 December 2020 and then until 11 February 2021. On 19 December 2020, the curfew was applied again in Slovakia, with several exceptions during the Christmas holidays. These restrictions have proven ineffective, so anti-pandemic measures were tightened on 31 December 2020 [42].

Mobility in the Slovak Republic has changed in connection with the measures taken. The largest decline in mobility was recorded in March and April 2020, with the declaration of a state of emergency during the so-called first wave of the pandemic in spring 2020. With the loosening of measures, there was a gradual increase in mobility. During the summer months of 2020, measures were loosened and the mobility of the population increased. On 1 October 2020, a new state of emergency was declared, and mobility began to gradually decline again. However, measures during the so-called second wave of the pandemic in autumn 2020 did not bring as significant a reduction in mobility as during the first wave of the pandemic. During this period, there was also an interruption of teaching at secondary schools and primary schools; this group of passengers represents a significant part of the demand for public passenger transport. From this date until the end of the year, we can observe fluctuating developments in the mobility of the population, which was based on the adopted anti-pandemic measures and the need of the population to travel by public passenger transport (Figure 2). 


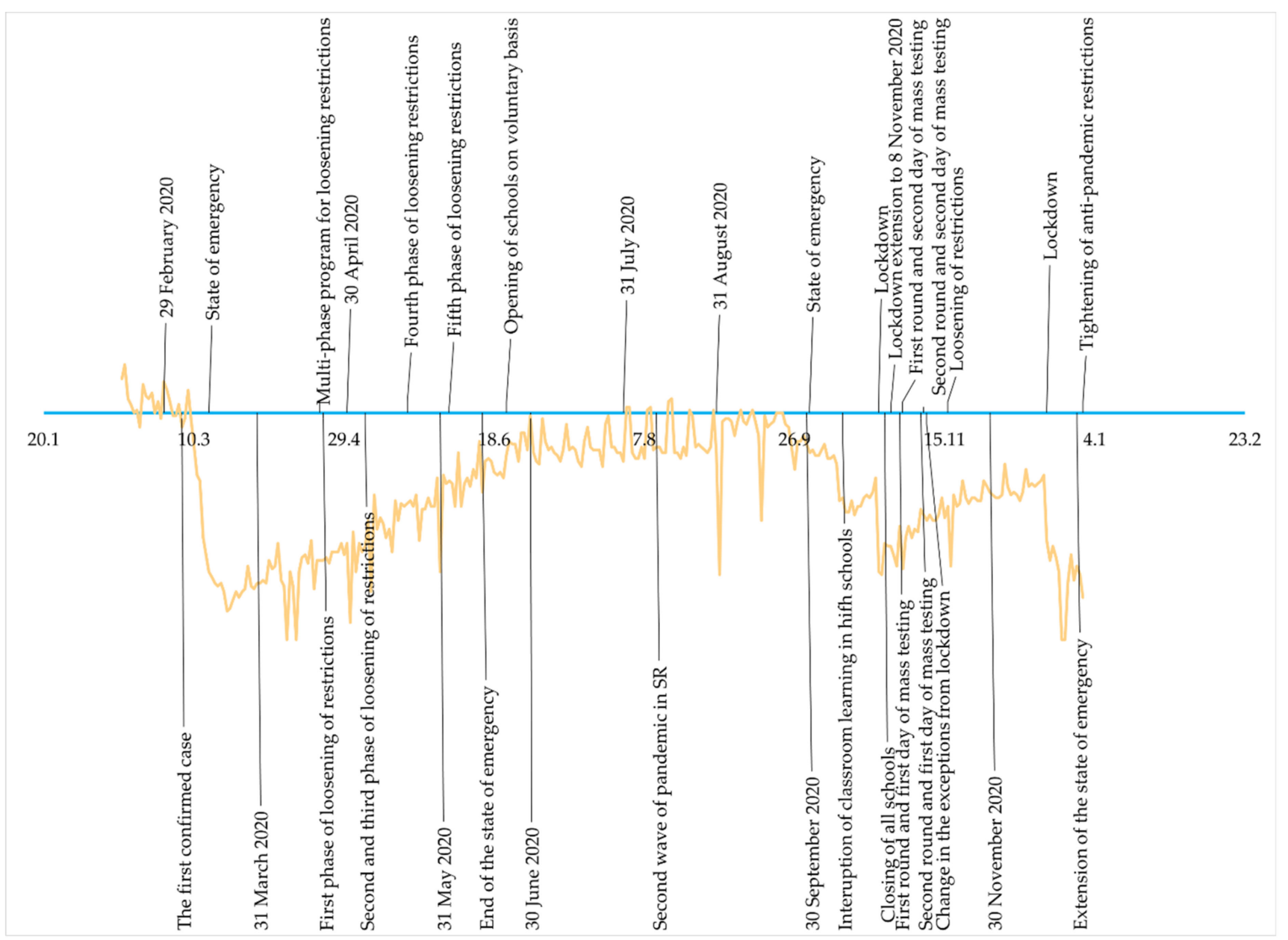

Figure 2. Development of mobility changes in the Slovak Republic, depending on the adopted anti-pandemic measures. Source: Elaborated by the authors on the basis of [43].

Due to the fact that measures within the Slovak Republic were taken at the national level, the mobility of the population in individual self-governing regions developed almost identically with the mobility of the population for the whole of the Slovak Republic. Within the Bratislava Region, we observed that the mobility of the population decreased compared to national mobility in the summer months. This phenomenon could be caused by the holiday season. We observed the opposite course of population mobility in the summer months in the Prešov Region, where mobility increased sharply. This phenomenon was caused by the loosening of measures and the fact that the region is oriented towards tourism. In the last period, mobility in both regions is almost identical to the mobility for the whole of Slovakia. Mobility in the Žilina and Košice regions copies mobility for the whole of Slovakia. The situation is almost identical in the Banská Bystrica and Trnava regions. Only in the summer months is the mobility of the population slightly higher compared to national mobility. In the Trenčín and Nitra regions, the mobility of the population is higher in the whole monitored period in comparison with national mobility.

We also monitored the mobility of the population from a regional point of view. As restrictions to stop spreading the COVID-19 were taken at the national level, the mobility of populations in self-governing regions developed almost identically with the mobility of the entire Slovak Republic. Mobility of population in regions is also influenced by the location of a region or by the offer of job opportunities. This example can be observed in the Bratislava and Prešov regions during the summer months, when restrictions were eased or canceled. In the Prešov region, the mobility of the population increased as the region was visited by several tourists. On the contrary, in the Bratislava region, mobility 
was lower compared to mobility for the entire Slovak Republic, which may also be due to the holidays. Apart from the summer months, mobility in both regions developed similarly (Figure 3).

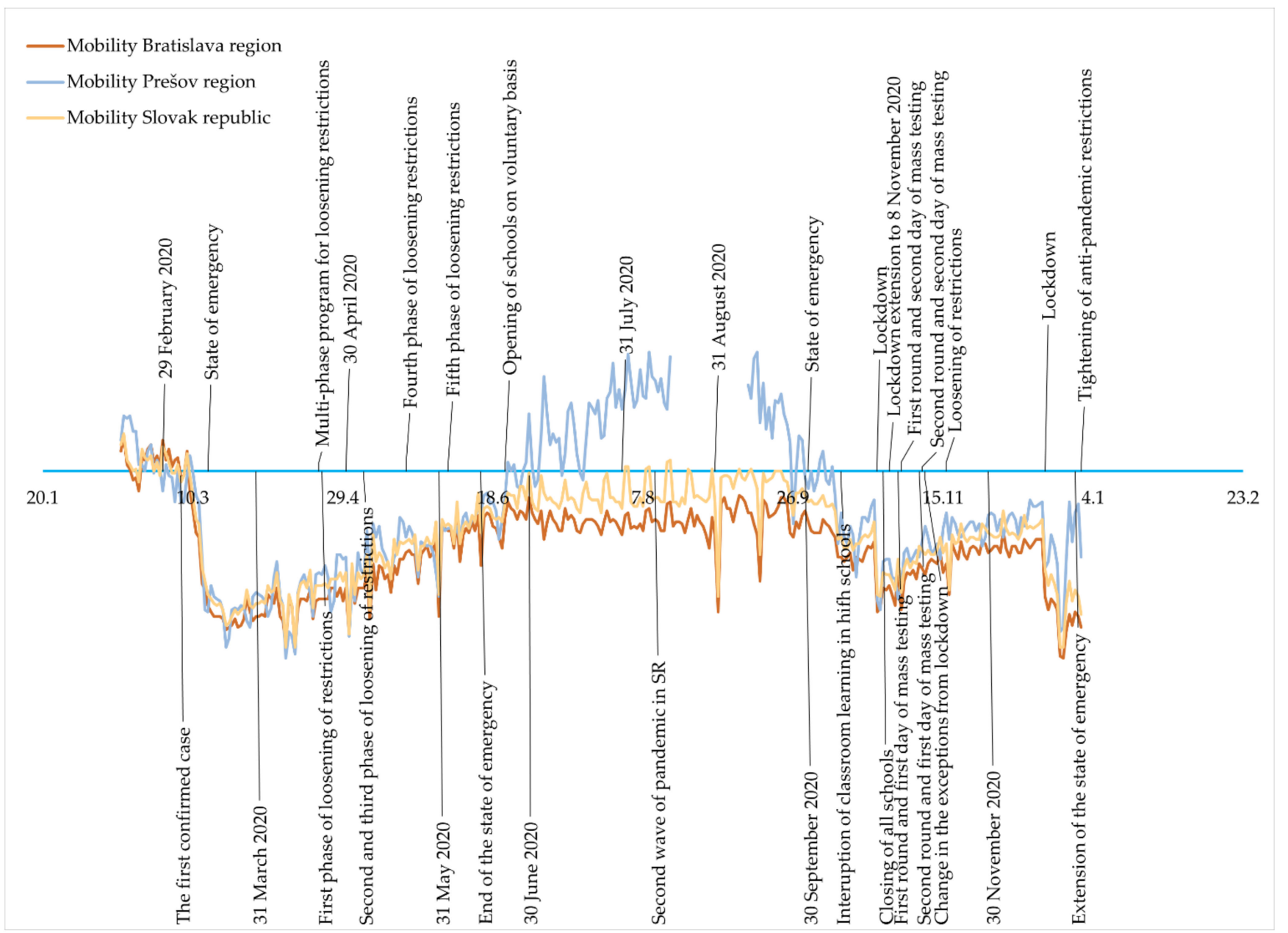

Figure 3. Changes of mobility in Bratislava self-governing region and Prešov self-governing region in comparison with mobility for the Slovak Republic, depending on anti-pandemic measures. Source: Elaborated by the authors on the basis of [43].

Mobility of populations in the Žilina, Banská Bystrica, Košice, and Trnava regions was almost identical to the mobility of the entire Slovak Republic. In the Banská Bystrica and Trnava regions, mobility was slightly higher in the summer months (Figure 4).

Mobility of populations in the Trenčín and Nitra regions was higher in the whole period monitored in comparison to national mobility. This phenomenon may be related to several industrial companies and factories, where there were no such major restrictions as there were in the area of services (Figure 5).

3.2. Impact of COVID-19 on Demand and Reduction of Demand for Suburban Bus Transport in the Žilina Self-Governing Region

Using Relations (8) and (9) and data on passenger demand in suburban bus transport in the Žilina self-governing region in the years 2013 to 2020, we calculated changes in demand in suburban bus transport by groups of passengers in 2020 compared to 2019 due to COVID-19. In the Žilina Region, there is a valid tariff for suburban bus transport, which includes ten groups of passengers. The results are shown in Table 2. 


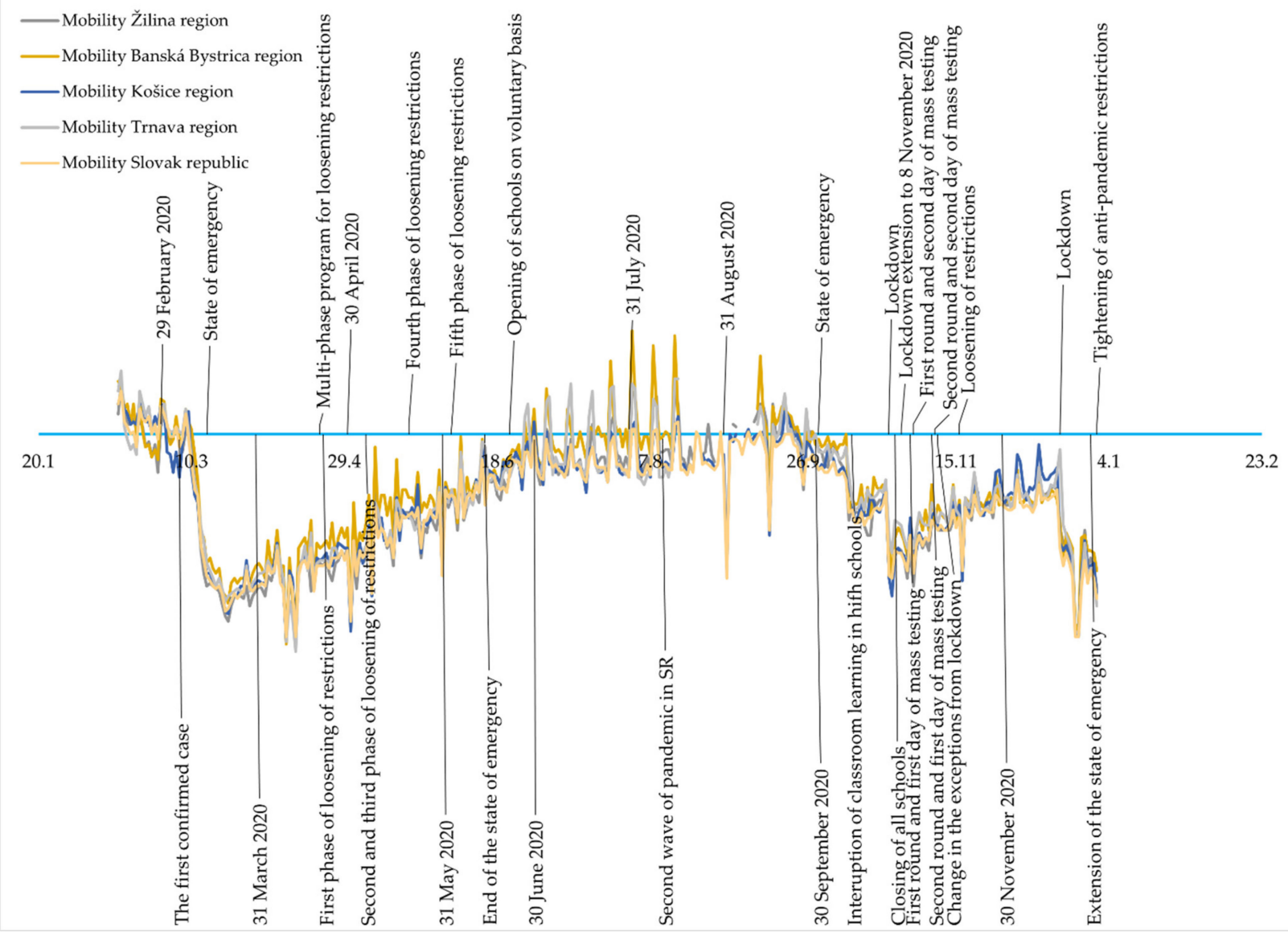

Figure 4. Changes of mobility in Žilina, Banská Bystrica, Košice and Trnava self-governing regions in comparison with mobility for the Slovak Republic, depending on anti-pandemic measures. Source: Elaborated by the authors on the basis of [43].

Table 2. Values of year-on-year change in demand in suburban bus transport in the Žilina self-governing region due to the COVID-19 pandemic in \%. Source: Prepared by the authors based on data from the Žilina self-governing region.

\begin{tabular}{ccccccccc}
\hline Group of Passengers & March & April & May & June & July & August & September & October \\
\hline Children (from 6 to 15 years) & -42.3 & -89.3 & -85.3 & -41.7 & -33.1 & -21.0 & -3.8 & -28.2 \\
\hline Children (up to 6 years) & -64.4 & -85.7 & -68.3 & -48.9 & -37.8 & -20.5 & -26.7 & -47.8 \\
\hline Disability card holder & -41.3 & -60.3 & -44.7 & -18.5 & -27.2 & -0.5 & -18.4 & -32.2 \\
\hline Reduced mobility person card holders & -50.3 & -71.5 & -54.7 & -28.6 & -34.2 & -7.7 & -22.7 & -59.6 \\
\hline Seniors over 65 years & -56.0 & -80.0 & -55.7 & -29.2 & -32.0 & -4.9 & -21.4 & -27.4 \\
\hline Adults & -33.4 & -52.8 & -41.3 & -15.2 & -22.4 & 2.9 & 16.7 & -31.2 \\
\hline Parents of the disabled children & -80.1 & -79.0 & -73.4 & -46.9 & -37.3 & -5.7 & -357.8 & -72.8 \\
\hline Guides for the disabled persons & -51.4 & -71.1 & -52.3 & -31.3 & -30.7 & -10.0 & -20.0 & -44.4 \\
\hline Pupils and students (16-26 years old) & -46.0 & -89.6 & -85.1 & -54.8 & -22.1 & -0.3 & -10.8 & -49.8 \\
\hline Special fare (for SAD employees) & -23.3 & -53.6 & -45.1 & -13.4 & 3.3 & 29.6 & 8.9 & -26.5 \\
\hline Summary & -40.2 & $-\mathbf{7 0 . 0}$ & $-\mathbf{6 0 . 2}$ & $-\mathbf{3 1 . 6}$ & $-\mathbf{2 4 . 4}$ & $-\mathbf{0 . 1}$ & $-\mathbf{1 2 . 6}$ & $-\mathbf{3 8 . 7}$ \\
\hline
\end{tabular}




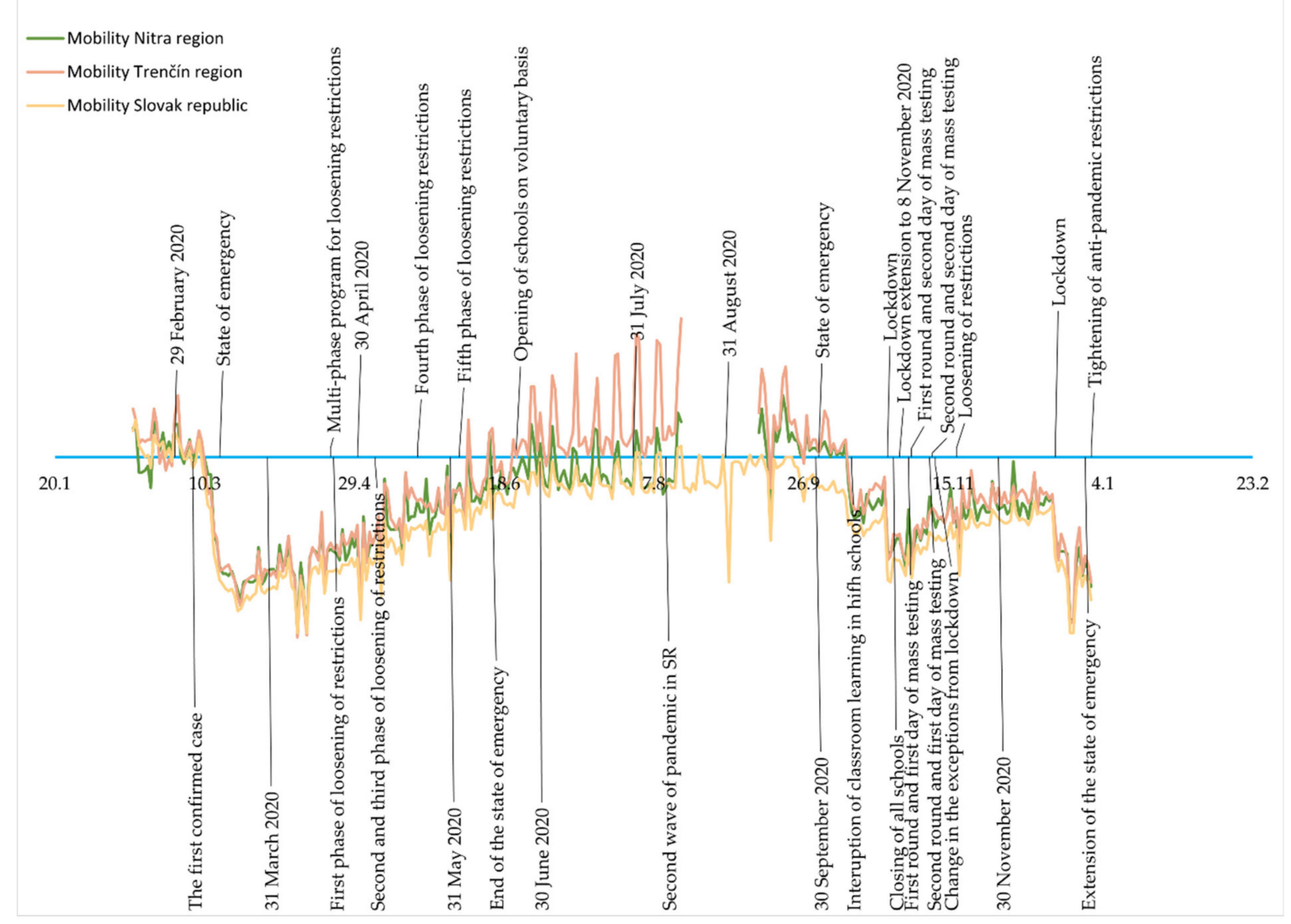

Figure 5. Changes of mobility in Nitra and Trenčín self-governing regions in comparison with mobility for the Slovak Republic, depending on anti-pandemic measures. Source: Elaborated by the authors on the basis of [43].

During the first wave of the pandemic in the Slovak Republic (March to June 2020), the largest decline in demand was in April 2020. Overall, demand fell by $70 \%$. The largest drop was in pupils and students $(-89.6 \%)$, children from 6 to 15 years $(-89.3 \%)$, children under 6 years $(-85.7 \%)$, and seniors over $65(-80.0 \%)$.

Figure 6 shows a comparison of the year-on-year change in demand in suburban bus transport in the Žilina self-governing region before and during the COVID-19 pandemic. The values in the figure represent a year-on-year decrease in demand caused only by the impact of the COVID-19 pandemic.

\subsection{Impact of the COVID-19 Pandemic on Short-Term Passenger Demand Forecasts}

We performed an ex-post forecast of the number of passengers transported by SBT in the Žilina self-governing region in 2019 in order to verify the suitability of using the stepwise autoregressive and exponential smoothing forecasting methods. For the forecast for 2019, a one-criteria time series of past values of the number of passengers using SBT in the Žilina region is used. The data are for individual months from 2013 to 2018. The results of both methods are shown graphically in Figures 7 and 8. In addition to the actual development of past demand, the figures contain the demand forecast for 2019, as well as lower $95 \%$ and upper $95 \%$ confidence limits for the variable Total number of passengers in PPT, default ALPHA $=0.05$.

The application of the exponential smoothing method for the ex-post forecast for 2019 provides logically uninterpretable results of negative demand; therefore, we do not consider this method further. Table 3 contains a comparison of actual demand in 2019 and the results of the ex-post forecast using the stepwise autoregressive method. 


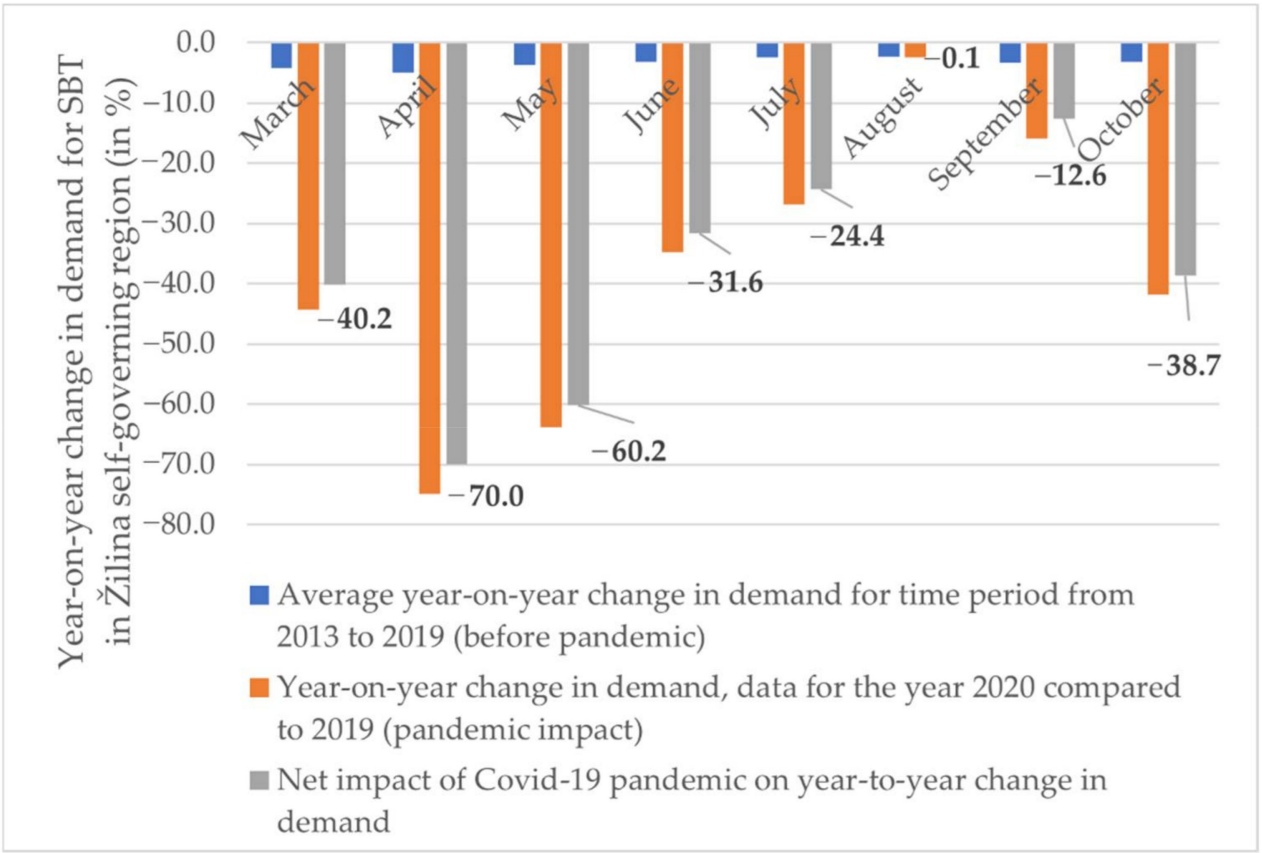

Figure 6. Year-on-year change in suburban bus transport demand in the Žilina self-governing region before the pandemic and at the time of the COVID-19 pandemic. Source: Prepared by the authors based on data from the Žilina self-governing region.

\section{Total number of passengers}

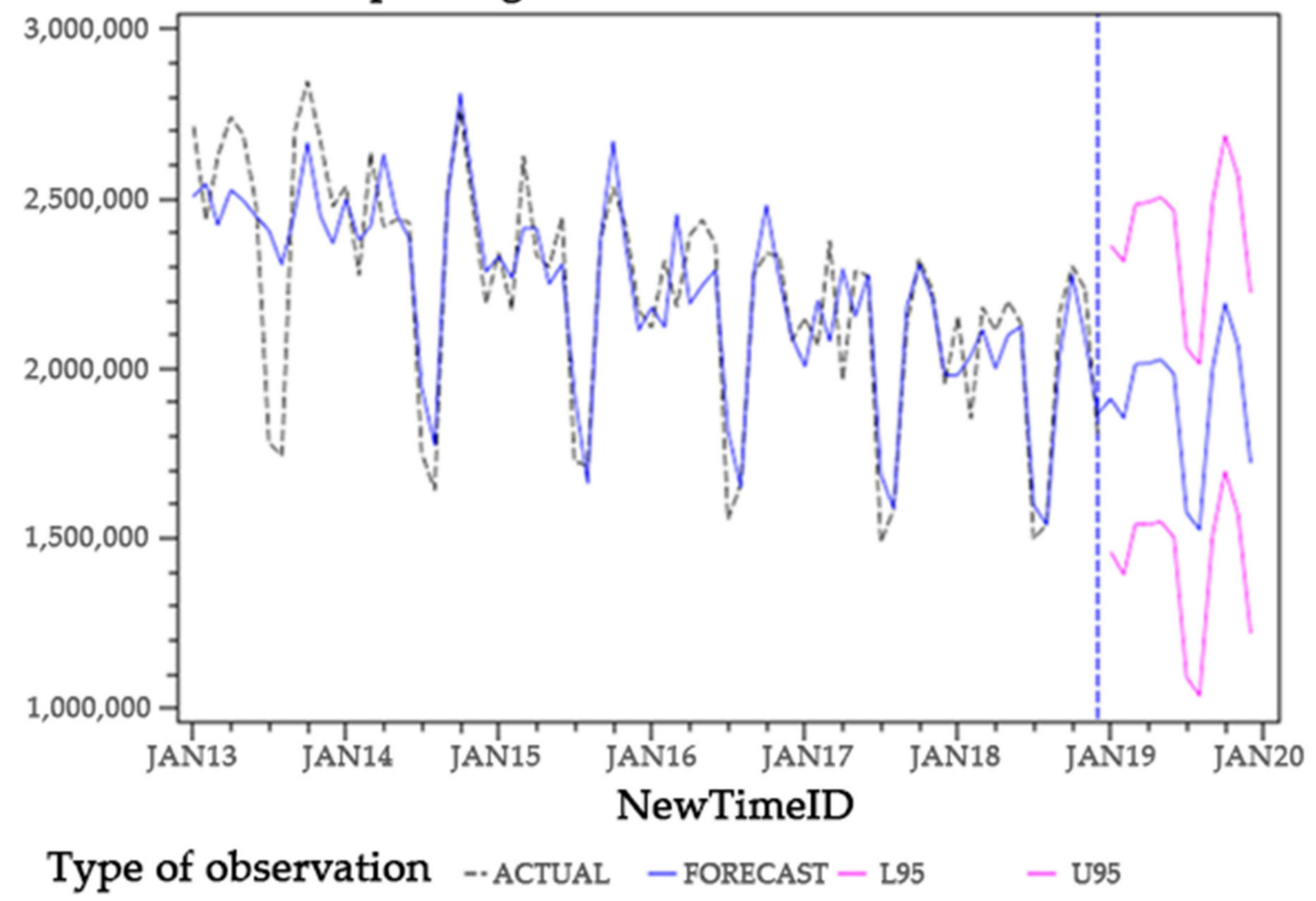

Figure 7. Forecast of the number of passengers using SBT in the Žilina self-governing region ex-post for 2019, using the stepwise autoregressive method. Source: Elaborated by authors using SAS software and data from the Žilina self-governing region. 


\section{Total number of passengers}

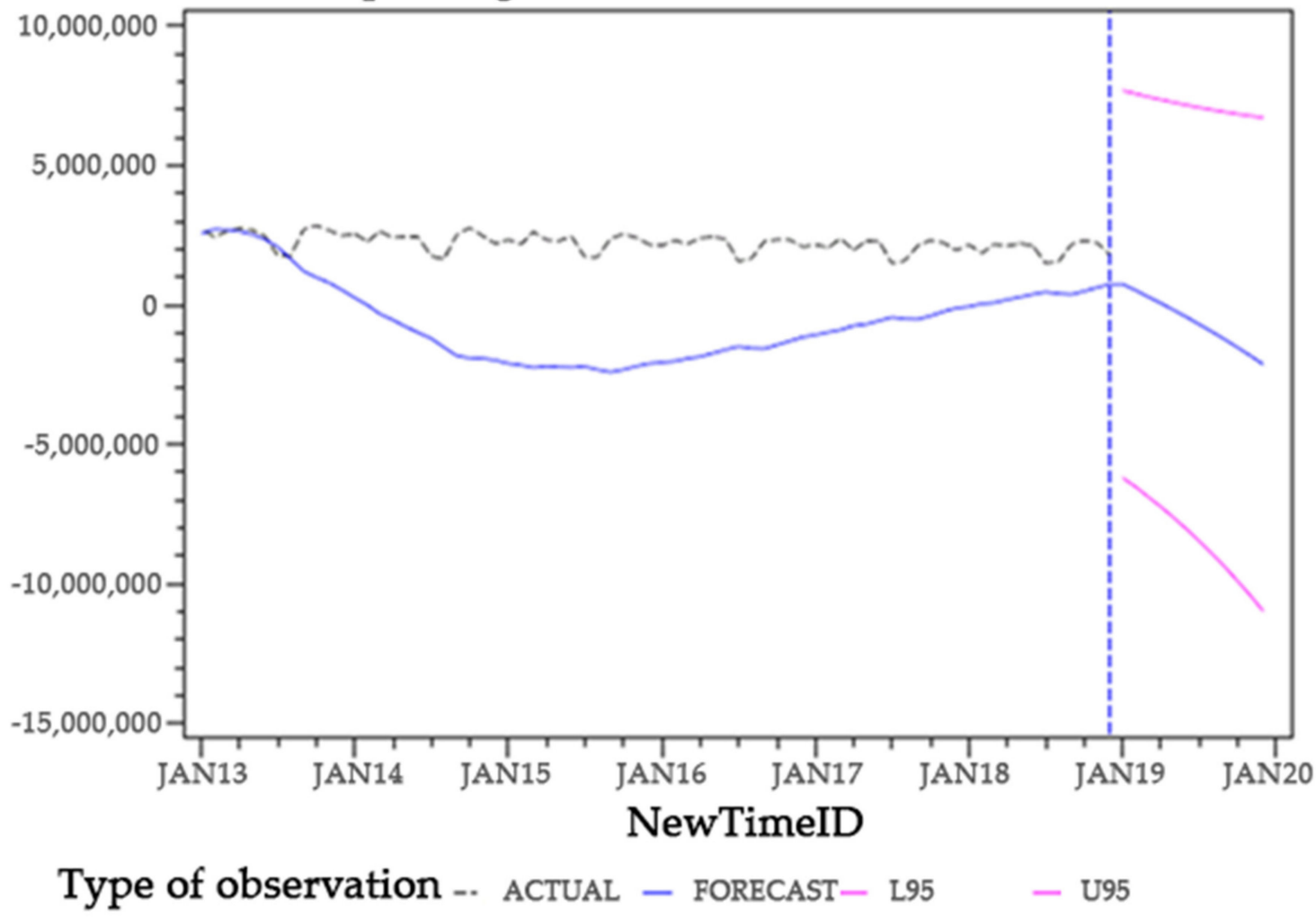

Figure 8. Forecast of the number of passengers using SBT in the Žilina self-governing region ex-post for 2019, using exponential smoothing. Source: Elaborated by authors using SAS software and data from the Žilina self-governing region.

Table 3. Comparison of real demand in 2019 and results of ex-post forecast using the stepwise autoregressive method. Source: Elaborated by authors using SAS software.

\begin{tabular}{ccc}
\hline Time Period & $\begin{array}{c}\text { Actual Demand } \\
\text { (Passengers) }\end{array}$ & $\begin{array}{c}\text { Ex-Post Demand Forecast Using the Stepwise } \\
\text { Autoregressive Method (Passenger) }\end{array}$ \\
\hline January 2019 & $2,152,900$ & $1,911,047$ \\
\hline February 2019 & $2,032,400$ & $1,853,927$ \\
\hline March 2019 & $2,036,366$ & $2,013,143$ \\
\hline April 2019 & $2,020,709$ & $2,015,623$ \\
\hline May 2019 & $2,153,079$ & $2,026,711$ \\
\hline June 2019 & $2,044,164$ & $1,984,328$ \\
\hline July 2019 & $1,540,335$ & $1,575,902$ \\
\hline August 2019 & $1,519,281$ & $1,524,516$ \\
\hline September 2019 & $2,200,886$ & $1,998,415$ \\
\hline October 2019 & $2,354,321$ & $2,192,396$ \\
\hline November 2019 & $2,155,495$ & $2,068,828$ \\
\hline December 2019 & $1,939,855$ & $1,722,824$ \\
\hline Year 2019 in total & $24,149,791$ & $22,887,660$ \\
\hline Forecast difference compared to actual demand (\%) & & -5.2 \\
\hline
\end{tabular}


3.3.1. Alternative No. 1-Forecast of the Number of Transported Passengers Using SBT in the Žilina Self-Governing Region in Total for the Years 2020 (November, December) and 2021

SAS software is used for short-term demand forecasting. The tool basic forecast, stepwise autoregressive forecast method is applied. The time series of the number of transported passengers using SBT in Žilina region, including the past development of demand in the years 2013 to October 2020, is calculated in months. The time series contains 94 observation values. We consider confidence level $95 \%$, lower $95 \%$ and upper $95 \%$ confidence limits, default ALPHA $=0.05$.

In the Figure 9 is a graphical output of the forecast of the number of transported passengers using SBT in the Žilina self-governing region by months for 2020 (November, December) and 2021. The time series of the number of transported passengers using SBT in the Žilina self-governing region is by months, including the past development of demand from 2013 to October 2020.

\section{Total number of passengers}

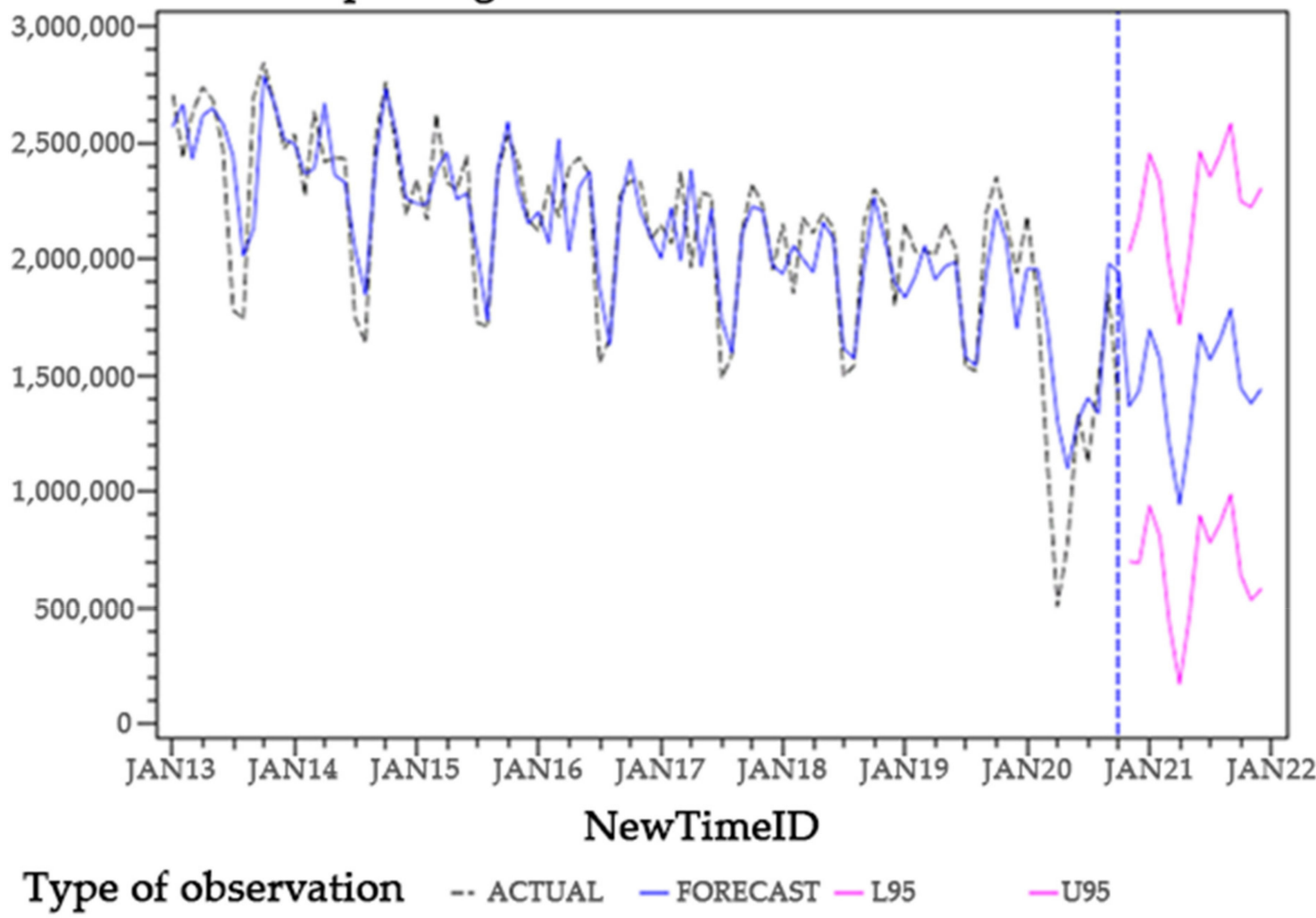

Figure 9. Number of transported passengers using SBT in the Žilina self-governing region in total from 2013 to October 2020, and forecast for 2020 (November, December) and 2021. Source: Elaborated by authors using SAS software and data from the Žilina self-governing region.

The values of the number of transported persons using SBT in the Žilina self-governing region for the years 2020 (November, December) and 2021 are provided in Table 4. According to the results of the short-term estimate, total demand is expected to decline.

3.3.2. Alternative No. 2-Forecast of the Number of Transported Passengers Using SBT in the Žilina Self-Governing Region in Total for the Years 2020 and 2021 from the Development of Demand before the Pandemic (until 2019)

This alternative to the demand forecast is based on past developments from January 2013 to December 2019. The time series has 84 values of past demand by months. Confidence level is $95 \%$, lower $95 \%$ and upper $95 \%$ confidence limits, default ALPHA $=0.05$. 
Table 4. Forecast of the number of transported persons using SBT in the Žilina self-governing region in 2020 (November and December) and 2021. Source: Elaborated by authors using SAS software.

\begin{tabular}{ccccc}
\hline \multirow{2}{*}{ Time Period } & $\begin{array}{c}\text { Estimated Number of Transported } \\
\text { Persons Using SBT Total (Persons) }\end{array}$ & L95 & STD & U95 \\
\hline November 2020 & $1,366,175.01$ & $700,883.18$ & $339,440.85$ & $2,031,466.85$ \\
\hline December 2020 & $1,435,963.96$ & $691,217.96$ & $379,979.43$ & $2,180,709.96$ \\
\hline January 2021 & $1,697,118.97$ & $938,774.47$ & $386,917.57$ & $2,455,463.48$ \\
\hline February 2021 & $1,570,930.36$ & $807,815.72$ & $389,351.36$ & $2,334,045.01$ \\
\hline March 2021 & $1,204,520.98$ & $436,332.77$ & $391,939.96$ & $1,972,709.19$ \\
\hline April 2021 & $944,994.43$ & $171,788.18$ & $394,500.23$ & $1,718,200.68$ \\
\hline May 2021 & $1,247,428.74$ & $469,276.20$ & $397,023.90$ & $2,025,581.28$ \\
\hline June 2021 & $1,680,980.05$ & $897,843.69$ & $399,566.71$ & $2,464,116.41$ \\
\hline July 2021 & $1,567,260.80$ & $779,080.58$ & $402,140.15$ & $2,355,441.01$ \\
\hline August 2021 & $1,659,841.71$ & $866,559.00$ & $404,743.51$ & $2,453,124.42$ \\
\hline September 2021 & $1,786,793.14$ & $988,350.60$ & $407,376.13$ & $2,585,235.68$ \\
\hline October 2021 & $1,445,589.35$ & $641,930.52$ & $410,037.55$ & $2,249,248.19$ \\
\hline November 2021 & $1,379,412.29$ & $533,428.18$ & $431,632.48$ & $2,225,396.40$ \\
\hline December 2021 & $1,442,938.25$ & $580,665.63$ & $439,943.10$ & $2,305,210.88$ \\
\hline Year 2021 in total & $\mathbf{1 7 , 6 2 7 , 8 0 9 . 0 7}$ & $\mathbf{8 , 1 1 1 , 5 4 8 . 5 4}$ & & $\mathbf{2 7 , 1 4 3 , 7 7 2 . 6 3}$ \\
\hline
\end{tabular}

We do not consider past data on actual demand in the 2020 pandemic. The aim is to estimate demand in 2021 using past values unaffected by the COVID-19 pandemic, then compare the results, reliability and accuracy with the results of Alternative no. 1.

In Figure 10 is a graphical output of the estimate of the number of transported passengers using SBT in the Žilina self-governing region by months for the years 2020 and 2021 for Alternative 2.

The values of the estimate of the number of transported persons using SBT in the Žilina self-governing region for the years 2020 and 2021 are provided in Table 5.

The result of the forecast of passenger demand for SBT in the Žilina self-governing region for Alternative 1 is 17,627,809 transported passengers in 2021; for Alternative 2 it is $21,694,394$ passengers. The considered impact of the pandemic in 2020 on the demand for SBT in the Žilina region caused a decrease in the estimated demand in 2021 by 4,066,585 passengers, which is a decrease of $18.7 \%$.

Forecasts of demand for SBT in the Žilina self-governing region in 2021, using SAS software for both alternatives of past values, are supplemented by estimation parameters, which are listed in Table 6. Parameter estimates include R-square type and forecast accuracy.

Despite the shorter time series, the demand estimation model is more reliable, and the estimation parameters reach higher values with this alternative.

Forecast accuracy is higher in the case of Alternative 2 compared to Alternative 1 . This state is confirmed by the values of the parameters of two types of forecasts.

The answer to the research question "What effect does the COVID-19 pandemic have on the forecasts of a one-dimensional time series of passenger demand?", is: the COVID-19 pandemic has the effect of reducing the accuracy and reliability of forecasting a one-dimensional passenger demand time series. 


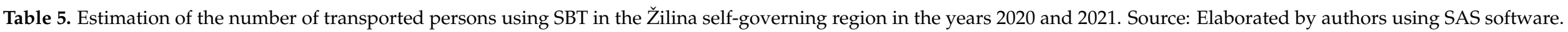

\begin{tabular}{|c|c|c|c|c|c|c|c|c|c|}
\hline Time Period & $\begin{array}{l}\text { Estimated Number } \\
\text { of Transported } \\
\text { Persons Using SBT } \\
\text { in Total (Persons) }\end{array}$ & 95 & STD & U95 & Time Period & $\begin{array}{l}\text { Estimated Number } \\
\text { of Transported } \\
\text { Persons Using SBT } \\
\text { in Total (Persons) }\end{array}$ & 95 & STD & U95 \\
\hline February 2020 & $1,936,172.09$ & $1,536,585.95$ & $203,874.22$ & $2,335,758.23$ & February 2021 & $1,844,479.96$ & $1,354,869.06$ & $249,806.07$ & 2,334,090.86 \\
\hline March 2020 & $1,925,870.25$ & $1,519,292.67$ & $207,441.35$ & $2,332,447.82$ & March 2021 & $1,840,558.85$ & $1,343,524.04$ & $253,593.85$ & $2,337,593.66$ \\
\hline April 2020 & $1,916,939.88$ & $1,507,837.07$ & $208,729.75$ & $2,326,042.68$ & April 2021 & $1,822,459.62$ & $1,320,718.02$ & $255,995.31$ & $2,324,201.21$ \\
\hline May 2020 & $1,999,898.14$ & $1,589,300.98$ & $209,492.20$ & $2,410,495.30$ & May 2021 & $1,870,299.40$ & $1,366,982.47$ & $256,799.07$ & $2,373,616.32$ \\
\hline June 2020 & $1,946,440.71$ & $1,534,331.38$ & $210,263.73$ & $2,358,550.04$ & June 2021 & $1,847,389.02$ & $1,342,155.03$ & $257,777.18$ & $2,352,623.00$ \\
\hline July 2020 & $1,589,753.98$ & $1,176,209.26$ & $210,996.08$ & $2,003,298.69$ & July 2021 & $1,599,719.13$ & $1,093,019.40$ & $258,525.02$ & $2,106,418.87$ \\
\hline August 2020 & $1,512,743.21$ & $1,097,732.58$ & $211,744.01$ & $1,927,753.85$ & August 2021 & $1,502,035.21$ & $993,813.27$ & $259,301.67$ & $2,010,257.14$ \\
\hline September 2020 & $2,015,555.01$ & $1,599,059.67$ & $212,501.53$ & $2,432,050.36$ & September 2021 & $1,860,238.33$ & $1,350,509.36$ & $260,070.58$ & $2,369,967.30$ \\
\hline October 2020 & $2,232,889.86$ & $1,814,885.49$ & $213,271.46$ & $2,650,894.24$ & October 2021 & $2,093,719.08$ & $1,582,464.91$ & $260,848.76$ & $2,604,973.25$ \\
\hline November 200 & $2,029,571.07$ & $1,610,033.86$ & $214,053.53$ & $2,449,108.27$ & November 2021 & $1,924,670.88$ & $1,411,873.12$ & $261,636.32$ & $2,437,468.65$ \\
\hline December 2020 & $1,795,744.37$ & $1,374,650.63$ & $214,847.69$ & $2,216,838.11$ & December 2021 & $1,682,431.47$ & $1,168,071.38$ & $262,433.44$ & $2,196,791.57$ \\
\hline Year 2020 in total & $22,862,923.38$ & $17,929,637.82$ & & $27,796,208.93$ & Year 2021 in total & $21,694,393.58$ & $15,655,103.62$ & & $27,733,683.53$ \\
\hline
\end{tabular}


Total number of passengers

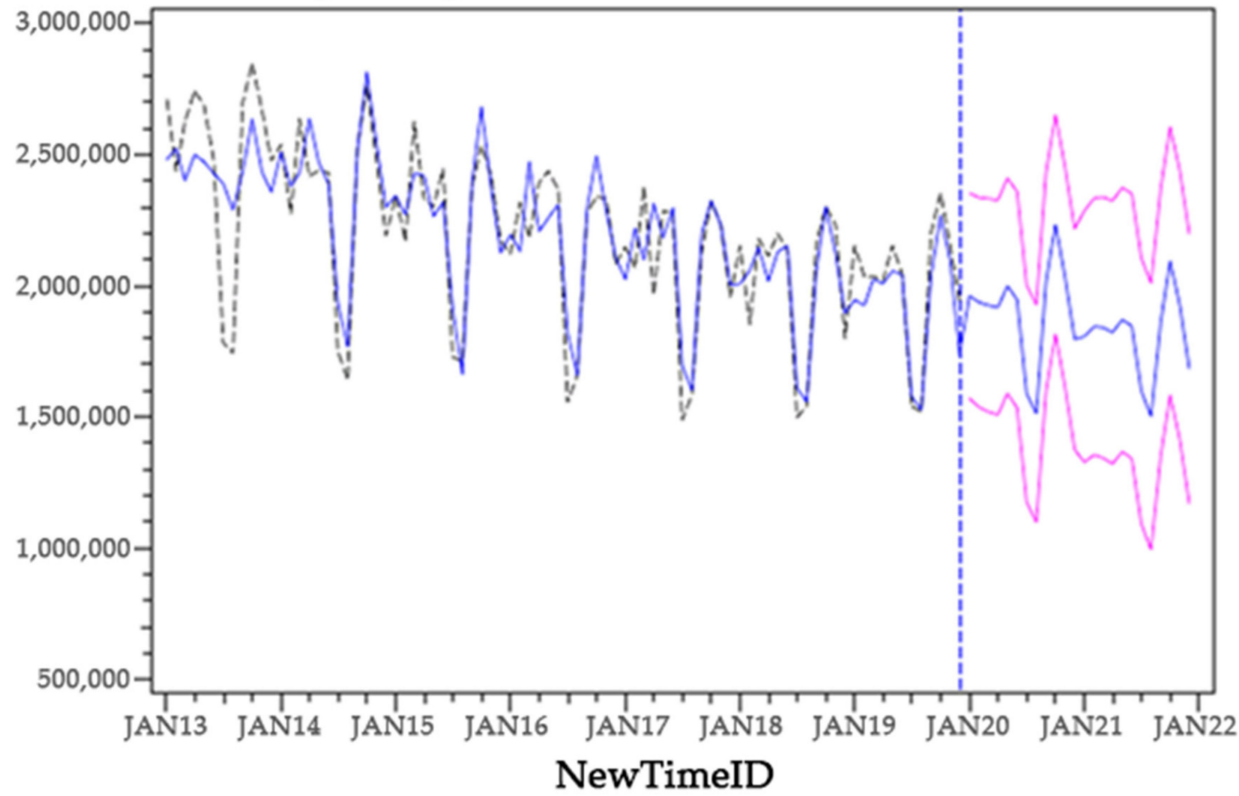

Type of observation -- ACTUAL - FORECAST - L95 -U95

Figure 10. Number of transported passengers using SBT in the Žilina self-governing region in total, from 2013 to 2019, and a forecast for 2020 and 2021 (without the effect of the pandemic). Source: Elaborated by authors using SAS software and data from Žilina self-governing region.

Table 6. Parameter estimates—forecast of demand for SBT in the Žilina self-governing region. Source: Elaborated by authors using SAS software, characteristics by SAS software.

\begin{tabular}{|c|c|c|c|c|}
\hline Observation & Parameter & Characteristic & $\begin{array}{l}\text { Alternative No. 1-Forecast } \\
\text { for } 2020 \text { (November, } \\
\text { December) and } 2021\end{array}$ & $\begin{array}{l}\text { Alternative No. 2-Forecast } \\
\text { for } 2020 \text { and } 2021\end{array}$ \\
\hline 1 & $\mathrm{~N}$ & $\begin{array}{l}\text { The number of non-missing observations used to fit the model } \\
\text { for the series }\end{array}$ & 94 & 84 \\
\hline 2 & NRESID & $\begin{array}{c}\text { The number of non-missing residuals, n, used to compute the } \\
\text { goodness-of-fit-statistics }\end{array}$ & 94 & 84 \\
\hline 3 & SST & The total sum of squares for the series, corrected for the mean & $\left(1.7794 \times 10^{13}\right)$ & $\left(9.2305 \times 10^{12}\right)$ \\
\hline 4 & SSE & The sum of the squared residuals, uncorrected for the mean & $\left(4.6522 \times 10^{12}\right)$ & $\left(2.2503 \times 10^{12}\right)$ \\
\hline 5 & MSE & $\begin{array}{l}\text { The mean squared error, calculated from } \\
\text { one-step-ahead forecast }\end{array}$ & $\left(5.2865 \times 10^{10}\right)$ & $\left(2.8485 \times 10^{10}\right)$ \\
\hline 6 & MAPE & The mean absolute percent error & 9.7892122 & 5.6681208 \\
\hline 7 & MPE & The mean percent error & -3.053093 & -0.406294 \\
\hline 8 & MAE & The mean absolute error & $161,995.59$ & $120,778.51$ \\
\hline 9 & ME & The mean error & -7351.658 & 5207.5912 \\
\hline 10 & MAXE & The maximum error (the largest residual) & $563,912.81$ & $278,146.29$ \\
\hline 11 & MINE & The minimum error (the smallest residual) & $-795,286$ & $-607,407$ \\
\hline 12 & MAXPE & The maximum percent error & 20.889691 & 11.70473 \\
\hline 13 & MINPE & The minimum percent error & -157.0762 & -34.08343 \\
\hline 14 & RSQUARE & The R square statistic & 0.7385547 & 0.7562104 \\
\hline 15 & ADJRSQ & The adjusted $\mathrm{R}$ square s statistic & 0.7236999 & 0.7438666 \\
\hline 16 & CORR & $\begin{array}{l}\text { The correlation coefficient between the actual values and the } \\
\text { one-step-ahead predicted value }\end{array}$ & 0.8618431 & 0.8699528 \\
\hline
\end{tabular}




\section{Discussion}

Our research from data on actual passenger demand in suburban bus transport in the Žilina self-governing region during 2020 by months, and the change in demand compared to January 2020, was also focused on a comparison with data on the change in mobility at public transport stations in the Žilina self-governing region from Google.

The course of changes in mobility is shown in Figure 11. The figure contains a comparison of the development of changes in passenger mobility in suburban bus transport in the Žilina self-governing region, as well as the development of changes in mobility at public transport stations in the Žilina self-governing region from Google. To objectify the comparison of changes in the number of transported persons and changes in mobility from Google, we determined, from the data available in [43], the median values of the change for each month on the basis of data from daily changes in mobility. The comparison is made for October 2020. Data on the actual demand for suburban bus transport in the Žilina self-governing region for November and December 2020 are not available.

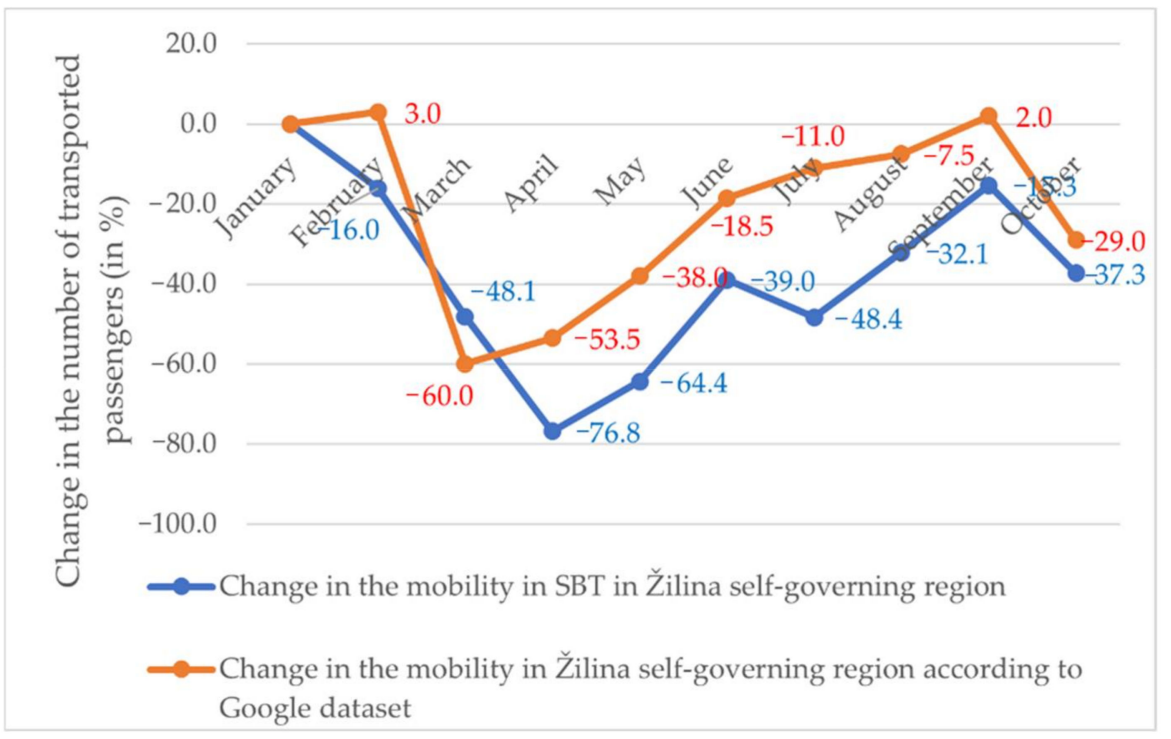

Figure 11. Changes in mobility in suburban bus transport in the Žilina self-governing region during 2020. Source: Prepared by the authors based on data from the Žilina self-governing region and [43].

The development of curves of changes in mobility in suburban bus transport in the Žilina self-governing region, as well as changes in mobility in the Žilina self-governing region based on data in [43], have a very similar course. These changes in values determined from two independent data sources correlate. A correlation coefficient was calculated which, in the period of the pandemic from March 2020 to October 2020, reaches the value of 0.758 . There is a strong direct relationship between the change in mobility and the change in the real demand for suburban bus transport in the Žilina self-governing region. Apart from the change in March 2020, the reduction in actual demand for suburban bus transport in the Žilina self-governing region is significantly lower compared to the reduction in mobility processed on the basis of data [43].

Differences may also be due to different levels of mobile phone use by groups of passengers using suburban bus transport in relation to positioning when collecting data on the mobility of the population within [43].

The course of mobility changes in the suburban bus transport for selected groups of passengers is shown in Figure 12. 


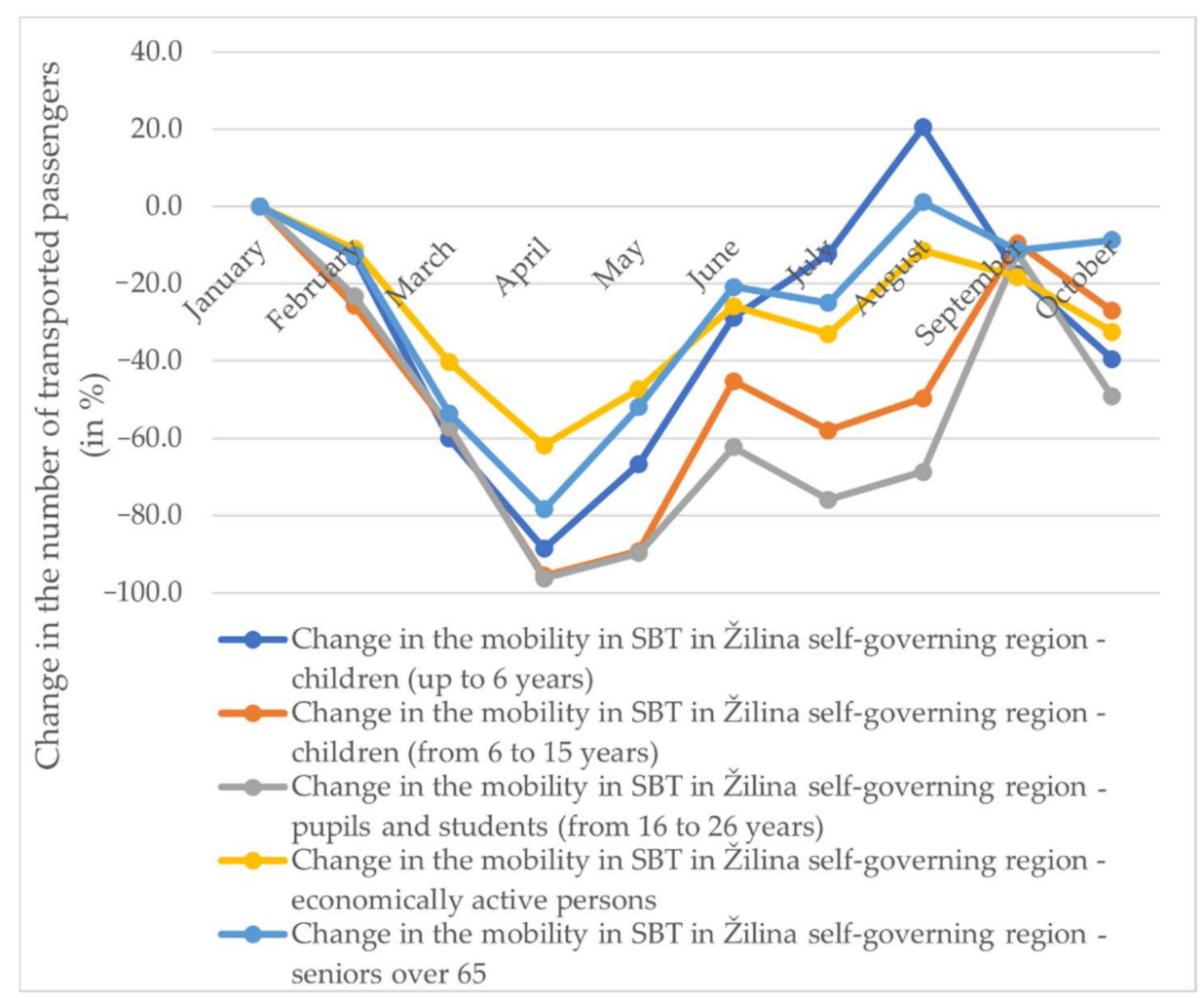

Figure 12. Changes in the mobility of selected groups of passengers using the suburban bus transport in the Žilina self-governing region during 2020. Source: Prepared by the authors based on data from the Žilina self-governing region.

In connection with our research presented in Sections 3.1 and 3.2, we express the following conclusions related to Research Question No.1.

Yes, there is a strong correlation between data on changes in passenger demand for SBT in the Žilina self-governing region and data on changes in mobility at public transport stations in the Žilina self-governing region. The following facts may be a barrier to achieving a higher value of the correlation coefficient between the examined data. Global data on changes in mobility in the regions of the Slovak Republic are collected for public passenger transport stations in a given region, not in relation to a specific transport system or a carrier serving a specific territory and specific public transport stops. The system of public passenger transport of a particular region consists of the systems of several carriers in railway passenger transport, suburban bus transport, and urban public transport. Global data on changes in mobility in the regions of the Slovak Republic and in the Slovak Republic are an important basis for evaluating the effectiveness of pandemic events; for this purpose, they are collected and published. For the planning and management of transport services in the area by public passenger transport, including its reasonable offer according to Act no. 56/2012 Coll. on road transport, data on demand and its changes in a specific transport system are necessary. Here, we must be critical of the unavailability of relevant statistics and their public provision, despite the fact that these services are in the public interest and the clients of these services (self-governing regions in regional transport and cities in urban transport) are public authorities financed by taxpayer resources.

When assessing the most represented groups of passengers, the largest change occurred in the group of pupils and students, and in children aged 6 to 15 years.

Our research has confirmed a significant decline in real demand for suburban bus transport. The decrease was more significant during the first wave of the pandemic in spring 2020 than in the second wave of the pandemic in autumn 2020. During the first wave of the pandemic in the Slovak Republic (March to June 2020), the actual number of passengers using suburban bus transport decreased from 31.6\% to $70 \%$. In October 2020, 
actual passenger demand for suburban bus transport in Žilina self-governing region decreased by $38.7 \%$.

Here, it is necessary to state that it is problematic to obtain official statistics on the demand for services of specific carriers in public passenger transport during the pandemic in 2020. Official statistics on the number of transported passengers for all carriers in the Slovak Republic are compiled in the Yearbook of Transport, Posts and Telecommunications of the Slovak Republic, which will be published, with data for 2020 only, in December 2021. From such compiled consolidated data for the whole Slovak Republic, it is problematic to examine the impact of the pandemic on the demand of individual groups of passengers in specific regions, because behavior and decision-making are regionally differentiated. The dependence of the population of the Slovak Republic on public passenger transport is different, and it increases with decreasing economic development across regions, from the western part of the Republic to the east. The procedures used by us to identify the impact of a pandemic on the demand for SBT can serve as models for similar research in individual regions of the Slovak Republic. Therefore, we want to highlight the approach of the Žilina self-governing region to provide a time series of data on the number of passengers carried by SBT in the pandemic year of 2020, and for the years before the pandemic. Only thanks to the data provided was it possible to implement our research.

These significant changes in mobility in the first wave of the pandemic compared to the second wave occurred despite the fact that several of the anti-pandemic measures taken by the government of the Slovak Republic during the second wave of the pandemic were stricter; some measures were at least at the level of the first wave.

A similar unevenness in the change in mobility in relation to anti-pandemic measures, in both waves of the pandemic in the Slovak Republic, was also confirmed by our research on the change in mobility at public transport stations based on Google data.

These findings from two independent data sources clearly indicate non-compliance with anti-epidemiological measures by the population, with respect to passengers during the second wave of the pandemic. This was reflected in a smaller decline in demand and mobility in the second wave.

The COVID-19 pandemic, which is causing changes in passenger demand, is affecting the consistency of a time series of past passenger demand. This may lead to a reduction in reliability and accuracy when determining future transport needs of passengers in a particular region in the context of drawing up transport service plans by transport customers and determining the scope of transport services in regional transport. The COVID-19 pandemic has had the effect of reducing the accuracy and reliability of the forecast of one-dimensional time series of future passenger demand. A time series of past demand for suburban bus transport in the Žilina self-governing region, supplemented by values from the pandemic year of 2020 used for forecasts of a single-criteria time series of demand, reduces the reliability of estimated future demand values compared to using a time series without pandemic data. This is also confirmed by the parameter estimates (R-square statistics, errors and correlation coefficients) within the alternative forecasts of a single-criteria time series of demand for 2021, as seen in the table in Section 3.3.

The supply of services in suburban bus transport is a significant factor in demand. Similar to research on changes in demand, we used data on supply in suburban bus transport in the Žilina self-governing region by months, for the period of years, and with Relations (4), (7) and (9).

The scope of supply of suburban bus transport services in the Žilina self-governing region was stable in the period before the pandemic (2013 to 2019), and the average yearon-year change in supply in this period was minimal, as shown in Table 7 and graphically represented in Figure 13. The COVID-19 pandemic and the associated decline in passenger demand facilitated decisions to reduce suburban bus transport supply in the Žilina selfgoverning region. 
Table 7. Year-on-year change in the SBT supply in the Žilina region before and at the time of the COVID-19 pandemic. [Authors].

\begin{tabular}{|c|c|c|c|c|c|c|c|c|}
\hline & March & April & May & June & July & August & September & October \\
\hline $\begin{array}{l}\text { Average year-on-year change in supply for the } \\
\text { period } 2013 \text { to } 2019 \text { (before the pandemic), [\%] }\end{array}$ & 0.2 & -0.6 & 0.1 & 0.2 & 0.2 & 0.1 & 0.3 & 0.2 \\
\hline $\begin{array}{l}\text { Year-on-year change in supply, data for } 2020 \\
\text { compared to } 2019 \text { (impact of pandemic), [\%] }\end{array}$ & -7.6 & -17.5 & -19.8 & -2.2 & 2.4 & 0.2 & -2.8 & -2.2 \\
\hline $\begin{array}{l}\text { Net impact of the COVID-19 pandemic on the } \\
\text { year-on-year change in supply, [\%] }\end{array}$ & -7.8 & -16.9 & -19.9 & -2.4 & 2.2 & 0.1 & -3.1 & -2.5 \\
\hline
\end{tabular}

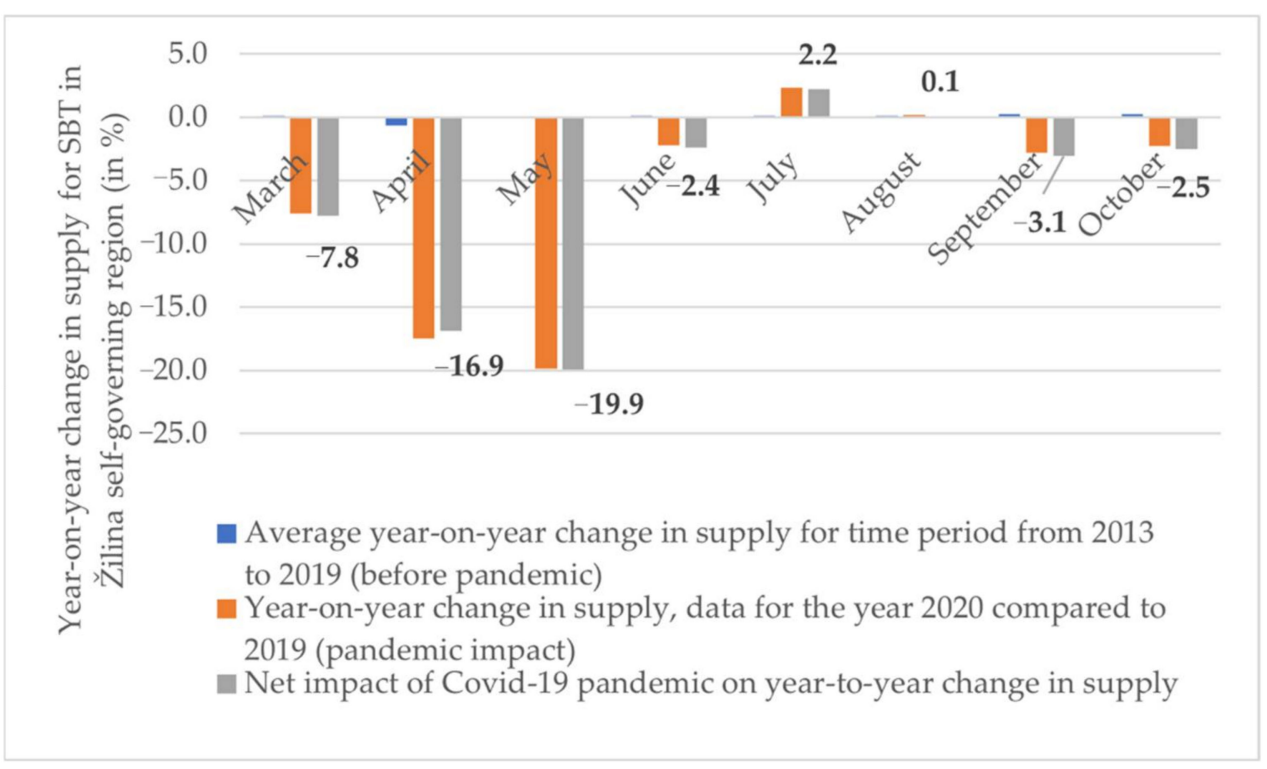

Figure 13. Year-on-year change in supply after suburban bus transport in the Žilina self-governing region before the pandemic and at the time of the pandemic caused by COVID-19. Source: Prepared by the authors based on data from the Žilina self-governing region.

The reduction in supply of suburban bus transport, expressed in terms of the number of kilometers traveled by buses on suburban bus transport, was due, in part, to declining passenger demand and reduced mobility during the period from March 2020 to October 2020. The bus service also operated on weekdays on a limited holiday or weekend routine.

During the COVID-19 pandemic, the benefits of public transport paradoxically became its shortcomings, and the use of passenger cars became an advantage, ideally with a minimum number of people in a car. However, this multiplies the impact of transport on the environment. The advantages of public passenger transport, including its qualitative parameters in the sense of the EN 13,816 standard, come to the fore. This is in conflict with the sustainability of passenger transport, not only in the conditions of the Slovak Republic but all over the world.

\section{Conclusions}

The COVID-19 pandemic has had a major impact on the mobility of the population and led to a significant reduction in real passenger demand for suburban bus services during 2020; this reduction was up to $70 \%$ in the first wave of the pandemic in April. The major effects of the pandemic are observable in the reduction in demand from groups of passengers such as pupils and students, children aged 6 to 15, children under 6 , and seniors over the age of 65 .

The mobility of the population in the Slovak Republic changed in the pandemic year of 2020 in connection with the measures taken by the government of the Slovak Republic. The largest decrease in mobility was recorded during the so-called first wave of the pandemic in the spring of 2020, in March and April 2020. With the gradual easing of measures, 
there was also an increase in the mobility of the population. In the autumn of 2020 (from 1 October 2020), a new state of emergency was declared, and mobility was reduced. Even the strict measures during the second wave of the autumn 2020 pandemic did not bring about such a significant reduction in mobility as during the first wave of the pandemic.

Our research in the conditions of the Slovak Republic in the Žilina self-governing region confirmed the strong, direct relationship between the change in mobility and the change in actual demand for suburban bus transport in the Žilina self-governing region in the pandemic year of 2020.

We also found differences in the effectiveness of anti-pandemic measures during the first and second waves of the pandemic, as confirmed by changes in population mobility and changes in actual passenger demand in suburban bus transport.

Self-governing regions are authorities that provide the conditions of Slovak Republic transport services by suburban bus transport and its financing. Several carriers have responded to the declining demand for suburban bus transport by reducing the supply of transport services in order to reduce operating costs. In the Žilina Region, the offer of suburban bus transport decreased year-on-year from $7.8 \%$ to $19.9 \%$ during the first wave of the pandemic, from March to May 2020, due to COVID-19, while supply decreased by $2.5 \%$ during the second wave of the pandemic in October 2020. Last but not least, declining demand was reflected in a decrease in transport revenues, as well as an increase in the demonstrable loss of carriers that perform their services in the public interest.

A time series of past demand for suburban bus transport in the Žilina self-governing region, supplemented by values from the pandemic year of 2020 and used for forecasts of a single-criterion time series of demand, reduced the reliability of estimated future values of demand. Estimated future demand values are an important part of SBT's transport service plans in ensuring an adequate supply of transport services in order to maintain demand. Cities and self-governing regions in the Slovak Republic will have to reconsider their transport service plans and prepare alternative estimates of demand, respecting the development of past demand at the time of the pandemic.

Only at the end of the pandemic, and with research into changes in passenger transport habits, will we know whether or not there has been a change in transport passengers in a particular transport system. Such research and its results will be one of the criteria in selecting a variant model for short-term passenger demand forecasting, with or without respect for past passenger demand at the time of the pandemic.

The reduction in passenger demand in the pandemic year will have an impact on the financing of suburban bus transport, and the level of demonstrable loss borne by carriers in self-governing regions is likely to increase. At the time of this research and the creation of this contribution, data on sales and demonstrable loss were not available.

Further research by the authors will also focus on changes in the transport habits of groups in the Slovak Republic due to the COVID-19 pandemic, asking to what extent the pandemic has affected passengers' decision-making. The research will incorporate key factors identified by Král et al., (2018) [45], which influence the decision-making of current and potential passengers in suburban bus transport. It will also be important to what extent passengers remain in the suburban bus transport system, with respect to whether they substitute suburban bus transport services for another type of public transport, or travel by car, bicycle, or on foot.

Further support for the integration of transport systems and the improvement of public passenger transport services, including suburban bus transport services in the conditions of the Žilina Region, as well as in other regions of the Slovak Republic, can be a tool for stabilizing and sustaining demand for public passenger transport during pandemics. It is also possible to use the experience published by Poliak et al., (2020) [46], which addressed the issue of promoting public passenger transport and integration in order to ensure the sustainable mobility of the population before the outbreak of the COVID-19 pandemic. 
Author Contributions: Introduction, M.B. and V.K.; literature review, M.B. and V.K.; materials and methods, M.B., V.K., and Š.S.; data curation, M.B. and V.K.; results, M.B. and V.K.; writing-original draft, Š.S.; visualization, M.B. and V.K.; final version, V.K. All authors have read and agreed to the published version of the manuscript.

Funding: The contribution was elaborated with the support of the Ministry of Education of the Slovak Republic: VEGA no. 1/0566/18 Konečný, V.: Research on the impact of supply and quality of transport services on the competitiveness and sustainability of demand for public transport. The contribution was elaborated with the support of the Ministry of Education of the Slovak Republic: VEGA no. 1/0245/20 Poliak, M.: Identifying the impact of changes in transport legislation on the competitiveness of carriers and transport safety.

Institutional Review Board Statement: Not applicable.

Informed Consent Statement: Not applicable.

Data Availability Statement: Not applicable.

Conflicts of Interest: The authors declare no conflict of interest.

\section{References}

1. Kalašová, A.; Harantová, V.; Čulík, K. Public transport as a part of shared economy. Arch. Automot. Eng. Arch. Motoryz. 2019, 85, 49-56. [CrossRef]

2. Polat, C. The demand determinants for urban public transport services: A rewiev of the literature. J. Appl. Sci. 2012, 12, 1211-1231. [CrossRef]

3. Paulley, N.; Balcome, R.; Mackett, R.; Titheridge, H.; Preston, J.; Wardman, M.; Shires, J.; White, P. The demand for public transport: The effects of fares, quality of services, income and car ownership. Transp. Policy 2006, 13, 295-306. [CrossRef]

4. Metz, D. Demographic determinants of daily travel demand. Transp. Policy 2012, 21, 20-25. [CrossRef]

5. Currie, G. Exploring links between the sustainability performance of urban public transport and land use in international cities. J. Transp. Land Use 2018, 11, 325-342. [CrossRef]

6. Holmgren, J. A strategy for increased public transport usage-The effects of implementing a welfare maximizing policy. Res. Transp. Econ. 2014, 48, 221-226. [CrossRef]

7. Diana, M. Measuring the satisfaction of multimodal travelers for local transit services in different urban contexts. Transp. Res. Part A Policy Pract. 2012, 46, 1-11. [CrossRef]

8. Cantwell, M.; Caulfield, B.; O’Mahony, M. Examining the factors that impact public transport commuting satisfaction. J. Public Transp. 2009, 12, 1-21. [CrossRef]

9. Abouhassan, M. Urban transport systems analysis. Wit Trans. Built Environ. 2017, 176, 57-68. [CrossRef]

10. Baldwin, R.; Weder di Mauro, B. Economics in the Time of COVID-19; Centre for Economic Policy Research: London, UK, 2020; ISBN 978-1-912179-28-2.

11. Joshi, A.; Bhaskar, P.; Gupta, P.K. Indian Economy Amid COVID-19 Lockdown: A Perspective. J. Pure Appl. Microbiol. 2020, 14, 957-961. [CrossRef]

12. Anderson, R.M.; Heesterbeek, H.; Klinkenberg, D.; Hollingsworth, T.D. How will country-based mitigation measures influence the course of the COVID-19 epidemic? Lancet 2020, 395, 931-934. [CrossRef]

13. Lewnard, J.A.; Lo, N.C. Scientific and ethical basis for social-distancing interventions against COVID-19. Lancet Infect. Dis. 2020, 20, 631-633. [CrossRef]

14. Abu-Rayash, A.; Dincer, I. Analysis of mobility trends during the COVID-19 coronavirus pandemic: Exploring the impacts on global aviation and travel in selected cities. Energy Res. Soc. Sci. 2020, 68. [CrossRef]

15. De Vos, J. The effect of COVID-19 and subsequent social distancing on travel behavior. Transp. Res. Interdiscip. Perspect. 2020, 5. [CrossRef]

16. Badr, H.; Du, H.; Marshall, M.; Dong, E.; Squire, M.M.; Gardner, L.M. Association between mobility patterns and COVID-19 transmission in the USA: A mathematical modelling study. Laancet Infect. Dis. 2020, 20, 1247-1254. [CrossRef]

17. Budd, L.; Ison, S. Responsible transport: A post-COVID agenda for transport policy and practice. Transp. Res. Interdiscip. Perspect. 2020, 6. [CrossRef]

18. Chen, Q.; Pan, S. Transport-related experiences in China in response to the Coronavirus (COVID-19). Transp. Res. Interdiscip. Perspect. 2020, 8. [CrossRef]

19. Tian, H.; Liu, Y.; Li, Y.; Wu, C.-H.; Chen, B.; Kraemer, M.U.G.; Li, B.; Cai, J.; Yang, Q.; Wang, B.; et al. An investigation of transmission control measures during the first 50 days of the COVID-19 epidemic in China. Science 2020, 368, 638-642. [CrossRef]

20. Li, K.; Yu, Q.; Jing, W.; Jubo, Y. Containing the virus or reviving the economy? Evidence from individual expectations during the COVID-19 epidemic. Ssrn Electron. J. 2020. [CrossRef]

21. Jiang, F.; Deng, L.; Zhang, L.; Cai, Y.; Cheung, C.H.W.; Xia, Z. Review of the clinical characteristics of coronavirus disease 2019 (COVID-19). J. Gen. Intern. Med. 2020, 35, 1545-1549. [CrossRef] 
22. Rodríguez-Morales, A.J.; MacGregor, K.; Kanagarajah, S.; Patel, D.; Schlagenhauf, P. Going global-Travel and the 2019 novel coronavirus. Travel Med. Infect. Dis. 2020, 33. [CrossRef]

23. Qiu, J.; Shen, B.; Zhao, M.; Wang, Z.; Xie, B.; Xu, Y. A nationwide survey of psychological distress among Chinese People in the COVID-19 epidemic: Implications and policy recommendations. Gen. Psychiatry 2020, 33, 1-4. [CrossRef]

24. Dong, H.; Ma, S.; Jia, N.; Tian, J. Understanding public transport satisfaction in post COVID-19 pandemic. Transp. Policy 2021, 101, 81-88. [CrossRef]

25. Shen, J.; Duan, H.; Zhang, B.; Wang, J.; Ji, J.S.; Wang, J.; Pan, L.; Wang, X.; Zhao, K.; Ying, B.; et al. Prevention and control of COVID-19 in public transportation: Experience from China. Environ. Pollut. 2020, 266. [CrossRef]

26. Dzisi, E.K.J.; Dei, O.A. Adherence to social distancing and wearing of masks within public transportation during the COVID 19 pandemic. Transp. Res. Interdiscip. Perspect. 2020, 7. [CrossRef]

27. Arellana, J.; Márquez, L.; Cantillo, V. COVID-19 outbreak in Colombia: An analysis of its impacts on transport systems. J. Adv. Transp. 2020, 2020, 8867316. [CrossRef]

28. Hensher, D.A.; Matthew, J.; Beck, E.W.; Balbontin, C. The impact of COVID-19 on cost outlays for car and public transport commuting-The case of the Greater Sydney Metropolitan Area after three months of restrictions. Transp. Policy 2021, 101, 71-80. [CrossRef]

29. Nižetić, S. Impact of coronavirus (COVID-19) pandemic on air transport mobility, energy, and environment: A case study. Int. J. Energy Res. 2020, 44, 10953-10961. [CrossRef]

30. Jenelius, E.; Cebecauer, M. Impacts of COVID-19 on public transport ridership in Sweden: Analysis of ticket validations, sales and passenger counts. Transp. Res. Interdiscip. Perspect. 2020, 8. [CrossRef]

31. Wielechowski, M.; Czech, K.; Grzeda, L. Decline in mobility: Public transport in Poland in the time of the COVID-19 pandemic. Economies 2020, 8, 78. [CrossRef]

32. Tarkowski, M.; Puzdrakiewicz, K.; Jaczewska, J.; Polom, M. COVID-19 lockdown in Poland-Changes in regional and local mobility patterns based on Google maps data. Transp. Geogr. Pap. Pol. Geogr. Soc. 2020, 23, 46-55. [CrossRef]

33. Borkowski, P.; Jazdzewska-Gutta, M.; Szmelter-Jarosz, A. Lockdowned: Everyday mobility changes in response to COVID-19. J. Transp. Geogr. 2020, 90. [CrossRef]

34. Ciechanski, A. Non-urban public bus transport against the COVID-19 pandemic-Evidence from the low Beskids and the Bieszczady counties. Transp. Geogr. Pap. Pol. Geogr. Soc. 2020, 23, 28-34. [CrossRef]

35. Coppola, P.; De Fabiis, F. Impacts of interpersonal distancing on board trains during the COVID-19 emergency. Eur. Transp. Res. Rev. 2021, 13. [CrossRef]

36. Bucsky, P. Modal share changes due to COVID-19: The case of Budapest. Transp. Res. Interdiscip. Perspectives 2020, 8. [CrossRef]

37. Gray, R.S. Agriculture, transportation, and the COVID-19 crisis. Can. J. Agric. Econ. 2020, 68, 239-243. [CrossRef]

38. Nicola, M.; Alsafi, Z.; Sohrabi, C.; Kerwan, A.; Al-Jabir, A.; Losifidis, C.H.; Agha, M.; Agha, R. The socio-economic implications of the coronavirus and COVID-19 pandemic: A review. Int. J. Surg. 2020, 78, 185-193. [CrossRef]

39. Žilina Self-Governing Region. Available online: http://www.zilinskazupa.sk/en/zilina-selfgoverning-region/regions/ (accessed on 6 April 2021).

40. Ministry of Health of the Slovak Republic. Available online: https: / www.health.gov.sk/Clanky?tlacove-spravy\&stranka=4 (accessed on 6 April 2021).

41. Public Health Authority of the Slovak Republic. Available online: https://www.uvzsr.sk/index.php?option=com_content\& view $=$ category \&layout=blog\&id=250\&Itemid=153 (accessed on 6 April 2021).

42. Coronavirus (COVID-19) in the Slovak Republic in Numbers. Available online: https://korona.gov.sk/en/coronavirus-covid-19 -in-the-slovak-republic-in-numbers/ (accessed on 6 April 2021).

43. Coronavirus (COVID-19). Available online: https://news.google.com / covid19/map?hl=sk\&gl=SK\&ceid=SK\%3Ask\&mid=\%2 Fm\%2F06ywnh (accessed on 6 April 2021).

44. SAS Software. Available online: http:/ / documentation.sas.com (accessed on 6 April 2021).

45. Kral, P.; Janoskova, K.; Klieštik, T. Key determinants of the public transport user's satisfaction. Adm. Si Manag. Public 2018, 31, 36-51. [CrossRef]

46. Poliak, M.; Poliaková, A.; Jaskiewicz, M.; Hammer, J. The need of public passenger transport integration. Ekon. Pregl. 2020, 71, 512-530. [CrossRef] 